\title{
Economic incentives and survival probabilities for chronic and multimorbidity patients - Do the relationships depend on patient pathways?
}

M. Kamrul Islam ( $\square$ kamrul.islam@uib.no)

Universitetet i Bergen https://orcid.org/0000-0003-4751-1513

Egil Kjerstad

NORCE Norwegian Research Centre AS

Jan Erik Askildsen

Universitetet i Bergen

Research article

Keywords: Coordination Reform (CR), Economic incentives, Patient pathways, survival probability, Multimorbidity, Difference-in-differences

Posted Date: November 6th, 2020

DOI: https://doi.org/10.21203/rs.3.rs-18071/v3

License: (c) (i) This work is licensed under a Creative Commons Attribution 4.0 International License. Read Full License 


\section{Abstract}

Background: The Norwegian Coordination Reform (CR) in 2012 introduced new economic incentives aimed at weaknesses in interaction between primary care, social care and specialist care. This paper studies the association of a new co-payment scheme on the 30-day and 90-day survival probabilities for

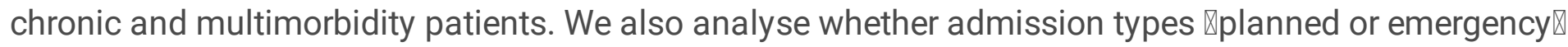
matters for survival rates, and the importance of patient pathways. Several different pathways are possible, depending on where patients came from before being admitted to hospital and their destination after discharge from hospital.

Methods: The study uses data from three different registers for the period 2010 to 2013 . We consider 30 common chronic conditions for which administrative data are available ( $n=563,096$ in-patient episodes). We look at three mutually exclusive pathways. They are relevant and important in terms of the number of patients depending on co-operation and co-ordination between health care providers. Using a quasiexperimental design-the difference-in-differences approach-we estimate the associations between the co-payment scheme and survival probability by admission type and by patient pathway.

Results: Overall, the changes in survival probabilities are found positively and significantly associated with the co-payment scheme. For emergency admissions such a significant positive association is observed for the 30-day survival only, whereas, for planned admissions a significant positive relationship is evident for the 90-day survival only. Pathway-specific results indicate positive and significant associations with survival probabilities (both the 30-and 90-day) for all admissions and emergency admissions for two specific pathways. Multimorbidity subgroup analysis generally shows no significant relationship with survival probabilities, but pathway-specific analyses show significant positive associations between emergency admissions and the 90-day survival for patients following two specific pathways. However, for planned admissions we find a significant negative association with the 30-day survival for multimorbidity patients following one specific pathway.

Conclusion: We conclude that the survival probabilities are positively associated with the new economic incentives but the result depends on admission type, patient pathway and multimorbidity status. Without modelling admission type, pathway and multimorbidity explicitly, one may overlook important relationships associated with the economic incentives. Future policy evaluations in any pertinent context should envisage these aspects.

\section{Background}

There is a rising prevalence of chronic conditions and multimorbidity worldwide. In a global context, chronic diseases are the largest cause of death $[1,2]$ In the US, chronic health conditions are the leading cause of death and disability and represent the largest component of health care costs [3, 4]. In Europe, the significance of chronic diseases in terms of deaths and health care costs are also well established [5]. Patients with chronic conditions and multimorbidity (defined as co-occurrence of two or more chronic 
conditions [6]) are the main users of health care services. Recent studies also show that multimorbidity patients account for up to 64 per cent of total health care expenditure [7]. Evidently, a substantial part of these expenditures could be avoided, in particular by reducing inefficiencies in health care organizations and delivery, and by substituting expensive specialist care with adequate and less expensive primary and home/social care.

Chronic conditions and multimorbidity affect a diverse range of individuals, and they require different kinds and even different combinations of health care services. There is recognition in most health care systems that health and social care delivery to these patients is sub-optimal, which has led many health authorities the world over to redesign their care provision. A concern is the lack of co-ordination between providers within the health and social care sectors. In particular, payment systems are often designed in a way that does not incentivize desired co-ordination, and thus creates a barrier for the desired patient flow, which should provide high-quality health and social care in a cost-efficient way.

Ideally, treatment of patients with chronic conditions and multimorbidity should occur through some kind of bundled payment $[8,9]$. In reality, an efficient form of bundled payment is difficult to implement because it will require expensive data and sophisticated systems of income sharing between units and independent systems, over time. However, as illustrated by Stokes et al. [8] in practice there are different payment systems that incorporate elements of bundling, for example, income sharing between treatment levels (primary care, social care, specialist care) and a specific time horizon that a particular remuneration covers. The provision of primary and social care services, including nursing homes and home care services, is the responsibility of municipalities (as in Norway), while the provision of hospital services is the responsibility of another authority (state-owned in Norway). Thus, the responsibility for discharged patients in need of follow-up and medical services is carried over from the state-owned hospitals to local governments. Likewise, referrals to specialist care are largely the responsibility of general practitioners (GP) under contract with local governments. They are gatekeepers and patients' advocates while having no financial obligations concerning admissions to hospital.

Trying to accomplish a reorientation of care, the health authorities in Norway implemented the Coordination Reform (CR) in January 2012 [10]. Patients with chronic conditions and/or multimorbidity constitute a substantial share of the patients targeted by the $\mathrm{CR}$. The reform was aimed at rectifying identified weaknesses in primary, social and specialist care interaction highlighted by the large number of patients not treated at 'the most effective level of care'. The White Paper argued that far too many people were admitted to hospital when they could have been taken care of at primary and social care, and far too many patients were staying in hospital for too long while waiting for follow-ups at the same services.

To facilitate better follow-up for chronic and multimorbidity patients specifically but not exclusively, the CR reform introduced new economic incentives consequential for both specialist care, primary care and social care. Rather than changing ownership structures and imposing more vertical or horizontal integration of service provision, the local authorities was incentivized to internalize some of the costs 
associated with both hospitalization and 'bed blocking', i.e., patients ready for discharge from hospital that awaits follow-up from the municipality in which they live.

The CR included three new economic incentives designed by the Government to affect the degree of coordination between health care providers and patient flows between them [10]. The co-payment scheme区 an instrument based on the idea that economic incentives potentially will change providers' behaviour》 was introduced as payment per admitted episode, equal to 20 per cent of the national average cost for the specific diagnoses-related groups (DRGs). However only medical diagnoses, not surgical diagnoses, were part of the co-payment system. The main aim was to incentivize municipalities to lower the demand for hospital services. The co-payment scheme ${ }^{[1]}$ was financed by reducing the allocations to the stateowned hospital sector by 20 per cent, with a corresponding re-allocation of the financial resources to municipalities. Municipalities received their share based on a per capita remuneration and dependent on pre-reform consumption of the relevant medical DRGs.

Critics of the CR scheme argued that people with chronic conditions, comorbidities and elderly patients, which are most likely to be affected if municipalities adapted to the incentive by providing more services locally, faced the prospect of receiving lower quality of health care services compared to the pre-reform situation [11]. A particular concern was that hospitals would have stronger incentives to shorten the length of stay (LOS) compared to the pre-reform situation, and that municipalities would have incentives to avoid hospitalization relying instead on the provision of medical resources of inferior quality.

Several aspects of the CR have been previously evaluated. Askildsen et al. [12]. concluded that the use of specialist somatic health care services did not change. Melberg and Hagen [13]. found that the LOS in

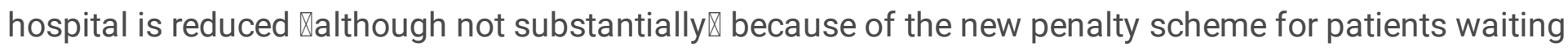
to be discharged. Ambugo and Hagen [14]. found little evidence that the new penalty scheme influenced death rates and readmissions for COPD/asthma, heart failure, hip fracture, and stroke. Islam and Kjerstad [15]. found negative associations between subsidies to municipalities establishing 24/7 emergency bed capacity (EBC) within their primary/social care facilities and changes in emergency admissions to hospitals.

Whether the quality of health services changed, however, is an issue that has been sparsely addressed. In a recent study, Bruvik et al. [16]. analysed the changes in survival following the CR with a small sample of patients living at a 35-bed short-term ward in a nursing home. They find that the number of patients that died in the nursing home after hospitalization doubled (27 per cent versus 13 per cent) following the CR while procedures and staffing were unchanged pre- and post-CR. Regarding patients' distribution, particularly the age distribution, they find that during the pre-CR, admitted patients were older (median 88 years, range 77-103 years) than the post-CR (median 85 years, range 77-99 years). Bruvik et al. [16] also found that shorter hospitalization periods for older patients led to an increase in the number of patients transferred to nursing homes. Referering to Gautun and Syse [17] and Abelsen et al. [11], Bruvik et al. [16] also concluded, 'The transfer of responsibility for treatment from hospitals to the municipalities entails 
that the patients being transferred suffer from more serious, complex and treatment-intensive conditions, when compared to the situation before the introduction of the co-ordination reform.'

For our part, we would add that other aspects of the distribution of patients may have contributed to the higher death numbers reported by Bruvik et al. [16]. For instance, Meacock et al. [18] in their study of mortality rates among emergency patients admitted to hospitals on weekends, found fewer deaths but higher mortality rates than for those admitted on weekdays. Their argument is that patients admitted on weekends are a selected group of patients. Because of the reduced availability of primary care services and higher threshold for admissions to accident and emergency facilities during weekends, fewer but sicker patients are admitted. Kahlon et al. [19] studied the association between frailty and 30-day mortality outcomes after discharge from hospital. They concluded that frailty at the time of admission is associated with a substantially increased risk of early readmission and death after discharge from medical wards. Monkerud and Tjerbo [20] show that municipalities do not seem to react to the CR changes in incentive structures by expanding their own rehabilitation capacity, rather they seem to take advantage of the fact that private institutions charge less than the prices they are facing under the copayment regime. The municipalities seemingly shift away from specialist rehabilitation services towards the use of rehabilitation services in private institutions. The goal as emphasized by policymakers was to incentivize a shift towards more municipal rehabilitation and less use of specialist rehabilitation.

It is of interest to study changes in health outcomes following policy interventions encompassing elements of bundling and co-ordinated payment systems, in particular, for patients with chronic conditions and multimorbidity. For example, elderly people receiving social care services at home or in a nursing home, services typically delivered by municipalities, may suddenly suffer a worsening of their physical functioning. Patients with chronic conditions and/or multimorbidity constitute a substantial share of the patients targeted by the CR. Although the empirical literature has highlighted the limitations of performance measures based on health outcomes, we find it relevant to analyse changes in mortality rates following a system reform, such as the $\mathrm{CR}$. One advantage of using mortality rates is that they are unequivocal. A higher mortality rate implies, everything else constant, poorer quality of health care services [21,22]. The 30-day mortality rate after admission to hospital is among the indicators considered to be effective for assessing the quality/outcome of hospital care [23]. The 30-day mortality after admission to hospital due to important chronic conditions, such as, acute myocardial infarction (AMI) and stroke is also considered one of the OECD Health care quality indicators [24]. The Norwegian Knowledge Centre for the Health Services (NOKC) suggests using 30-day survival probabilities as routinely reported quality indicators for Norwegian hospitals (see e.g. [25]). As a further control, we also use a 90-day survival.

The main contribution of this paper is to add to the knowledge base concerning how changes in financial incentives influence survival rates for patients with chronic conditions. We use registry data with a battery of contextual (i.e. municipality-level primary and social care attributes) and patient-level control variables. Using a quasi-experimental design-the difference-in-differences (DiD) approach-we estimate several models to test the robustness of the results. Importantly, we have variables that identify patients' 
pathways between providers of health care. We study three mutually exclusive pathways. These pathways are the important ones in terms of the number of patients dependent on co-operation and coordination between state and municipal health care providers:

(i) Home-Hospital-Home (hereafter referred to as Ho-H-Ho), where patients are admitted to hospital from home, discharged from hospital and returned home again.

(ii) Home-Hospital-Social Care Institution (hereafter referred to as $\mathrm{Ho}-\mathrm{H}-\mathrm{Sc}$ ), where patients are admitted to hospital from home, discharged from hospital and admitted to a social care institution, and

(iii) Home/and or Social care to Hospital to another Hospital (hereafter referred to as Ho-H-Oh), where patients are admitted to hospital from home/social care, discharged from hospital and admitted to another specialist hospital.

We hypothesize that through better coordination between hospital in charge of treatment, the new economic incentives may affect the distribution of patients allocated to the specific pathways, which in turn will influence both the 30 and 90-day survival probabilities compared to the pre-CR situation. The underlying rationale of our hypotheses is that the changes in economic incentives following the CR potentially encourage municipalities to allocate resources differently. Our assumption is that the change in payment systems may alter the distribution/group of patients referred to hospitals, which in turn potentially influences survival rates. However, the compound effect of the CR is difficult to predict a priori. If patients referred to and admitted to the hospitals were older and more fragile during the post-reform compared to the pre-reform situation, then survival rates may be reduced due to the mechanism outlined by Meacock et al. [18]. On the other hand, hospitals are best at treating the "critical/bad cases", so the new "division of labour" could actually increase survival rates due to a combination of demand and supply effects. Thus, even with a constant demand for hospital services, a more efficient distribution of patients between municipalities and hospitals would allow hospitals to concentrate on more specialised and complicated health services. As a result, more attention to cohesive patient pathways would benefit patients in need of specialised services, and in turn, survival rates may increase..

One might think that the changes in the distribution of patients are patient pathway-specific dependent. In particular, one might think that the distribution of patients following the $\mathrm{H}_{\mathrm{o}}-\mathrm{H}-\mathrm{H}_{\mathrm{o}}$ pathway would not be changed due to the new economic incentives, and in turn, the reform may have null effect on average survival probabilities for patients following this pathway.. Compared to the pre-CR situation, one may predict that patients still are likely to be provided formal and/or informal care[2] at home. Patients following the second and third pathways $\varangle \mathrm{H}_{\mathrm{o}}-\mathrm{H}-\mathrm{S}_{\mathrm{C}}$ and $\mathrm{H}_{\mathrm{o}}-\mathrm{H}-\mathrm{O}_{\mathrm{h}}$ खare obviously more dependent on formal care. Our argument is that the change in economic incentives leads to a "selection" of patients: The potentially frailer patients are admitted to hospital, and upon discharge, they are transferred either to nursing homes $\left(\mathrm{S}_{c}\right)$ or to another type of specialist health care institutions $\left(\mathrm{O}_{h}\right)$. Thus, the CR-reform may have countervailing effects: On the one hand, patients are frailer, patients are significantly different on average from the pre-CR situation, indicating reduced survival rates. On the other hand, assuming the 
coordination between hospital in charge of treatment and nursing home or "follow-up" hospital after discharge is adequate, then the post-reform changes in the process and management of patients would be positively impacted survival probabilities for patients following these pathways.

[1] The co-payment regime was abolished early 2015, the main arguments being that the scheme did not work as envisaged and that it placed too much risk on the municipalities, many of them small.

[2] Unfortunately, we do not have data on informal care time given at home.

\section{Methods}

\section{Data and variables}

Our patient data come from the Norwegian Patient Registry (NPR), from which we extracted information on different in-patient hospital admissions (emergency or planned admissions), patient age, gender, diagnoses, admission and discharge dates, death date, patient pathways, DRG codes etc. The primary NPR dataset contains only the main diagnosis of patients admitted to hospital (available until the year 2014 at our disposal). We obtained another dataset from the NPR with not only the main diagnosis but also the secondary diagnoses involving important chronic conditions. This information is useful for defining the multimorbidity status (co-occurrence of two or more chronic conditions) of the patients. One limitation of the data set is that the data with secondary diagnoses is presently available only through 2013. However, the effects of the CR on survival are likely to be stronger for chronic illness with complex needs than for the majority of in-patient admissions[1]. Thus, the study uses subset of NPR data, and two other registry data sets, namely, Statistics Norway (SSB)'s dataset on patients' socio-economic conditions, and KOSTRA (Municipality-State-Reporting) data set on municipal level attributes for the period 2010 to 2013 (two years pre-reform and two years post-reform).

During our study period, there were roughly 3.18 million in-patient admissions with length of hospital stay (LOS) greater than or equal to one day, and where 67 per cent of admissions were emergencies and the rest were planned. This study considers 30 important chronic and long-term conditions for which administrative data are available, and these conditions are also used in the previous literature $[9,26]$. These 30 diagnoses consist of, for example, alcohol abuse, asthma, atrial fibrillation, cancer, lymphoma cancer, metastatic cancer, chronic heart failure, chronic kidney disease, chronic pain, chronic pulmonary disease, chronic viral hepatitis $B$ and cirrhosis (see Appendix for the 30 chronic conditions with their ICD10 codes; [26], Table 1, p 31).

In general, a DRG payment covers all charges associated with an in-patient stay from the time of admission to discharge. Under a DRG-based system, a hospital's income depends on the price per DRG, and the number of patients discharged within each DRG. We define an in-patient stay as an episode of 
treatment requiring the patient to remain in hospital for a minimum of 1 night, (i.e. episode-specific LOS equal to or greater than one day) [2]. To define a patient's treatment during an episode, we constructed episodes by using patient identifiers, DRGs, and admission dates. Our subset of NPR data involves 563,096 in-patient episodes (around 78 per cent of emergency admissions) with LOS > $=1$. Table 1 describes the name and definition of the variables used in our analyses. After including all covariates in our models, because of some missing data for a few covariates, our final dataset consists of 547,101 inpatient episodes, where 435,465 episodes were emergencies and the other 111,636 episodes were planned (Table 2).

Table 2 further describes the number of patients for the surgical DRGs and medical DRGs by emergency and planned admissions, in both the pre- and post-reform periods. The number of patients in the groups are rather stable during the pre- and post-reform periods. In particular, in pre-reform period, the total number of patients in surgical group were 60,670 (where 31,510 were emergency admissions and the rest were planned admissions) and the post-reform the number slightly increased to 63,327 (where 31,627 were emergency admissions). For the medical group the number of patients were 211,146 (186,177 were emergency admissions) in the pre-reform period) and increased to $211,958(186,151$ were emergency admissions) during the post-reform period.

We have argued that the pathways that patients follow between service providers may affect survival rates. As mentioned before, our NPR data consist of two variables that identifies the patient pathways between providers of health care. To determine whether discharged patients are in need of social care services or another health care services, we used these variables describing the patients' pathway after discharge from hospital, and place of residence before and after hospitalization. Table 3 details patient distribution by pathways, comparing the pre- and post-reform periods. Notice that the absolute number of patients following the different pathways changes. While the $\mathrm{H}_{\mathrm{o}}-\mathrm{H}-\mathrm{H}_{\mathrm{o}}$ pathway is stable, the number of patients using the $\mathrm{H}_{\mathrm{o}}-\mathrm{H}-\mathrm{S}_{\mathrm{c}}$ pathway nearly doubled from 11,567 patients to 22,603 patients. The number of patients following the $\mathrm{H}_{\mathrm{o}}-\mathrm{H}-\mathrm{O}_{\mathrm{h}}$ pathway decreased by approximately 4,000 patients.

This study defines two dichotomous dependent variables based on survival probability after in-patient hospitalization per episode of admission. The first dependent variable is equal to 1 if a patient survived for 30-days (surv_30), and the second variable equal to 1 if a patient survived for 90-days (surv_90). The reduction in the LOS during the post-CR period is an important reason for measuring survival probabilities from admission to hospital.

Independent variables describe both individual patient-level and municipality-level attributes.. To control for patient heterogeneity, we include four age categories, and gender. Three variables are included to capture the complexity and severity of patients. A categorical variable capturing the multimorbidity status (multi) of the patient is defined if the number of chronic comorbidities is greater than or equal to 2[3]. The second variable accounts for case mix heterogeneity and is defined by the yearly-adjusted DRG prices (hrg_log).[4] The third variable includes the hospital length of stay (LOS). Endogeneity could be a potential problem for LOS, in particular. To limit this problem, instead of using patient day(s) of LOS, we 
constructed an average LOS variable by DRG, hospital and year, and subtract this average LOS from patient's day(s) of LOS. We then construct a dummy variable (LOS_M) equal to 1 if patient's in hospital LOS is greater than average LOS[5].

Since Norwegian municipalities are responsible for providing primary health care and social care, we control for municipality relevant attributes (time-varying).. In particular, to control for the magnitude and quality of primary care services, we include the number of patients per GP and percentage of the GPs with open lists (as an indicator of effective supply of primary care in municipalities) [27]. Proxy variables for social care service capacity in municipalities are the number of home care receivers relative to the number of inhabitants aged 80 years and over ('home care') and the number of institutional care receivers relative to the number of citizens aged 80 years and over ('institution care'). We further include a municipality-level attribute describing the 'quality of services' offered at social care institutions, such as physician hours per week available for the residents in nursing homes (Phy_Inst). A priori, we believe a higher number of physician hours in nursing homes indicates higher quality of services, associated with higher survival probability because the care of discharged patients is better facilitated than with municipalities with lower physician capacity. We also control for the share of inhabitants living alone at home, as an indicator of formal care needs. Table 1 describes the variables used in the analyses.

\section{Analytical strategies}

\section{All chronic and multimorbidity patients}

We examine whether economic incentives provided under the CR in Norway associated with the 30-day and 90-day survival probabilities for chronic and multimorbidity patients. In particular, we explore the associations from introducing a municipal co-payment of 20 per cent of the national DRG price, paid by the home municipality of the patients when they are admitted to hospital. Most notably, the scheme was introduced for medical DRGs only, not for surgical diagnoses. We use this difference as an identifying restriction by assuming that the expected change in survival probabilities for a patient admitted for surgical DRGs (control group) is the same as it would have been for the medical DRGs (treatment group) in the absence of the 20 per cent co-payment (the reform). The quasi-natural experiment design in this context is one where we observe outcomes (the 30-day and 90-day survival probabilities) for two groups for the pre-and post-reform periods. The treatment group is exposed to a treatment in the second period (after the reform), but not in the first period (before the reform), whereas the control group is not exposed to the treatment during either period. Using a quasi-experimental framework, we estimate a standard DiD equation, which is expressed while including all pathways as: 
$s_{i j t}=\beta_{0}+\beta_{1} R_{t}+\beta_{2} T_{i}+\boldsymbol{\beta}_{3} R_{t} \times T_{i}+\beta_{4}$ multi $_{i}+\beta_{4} \boldsymbol{P}_{i}+x_{i j t}^{\prime} \delta+m_{j t}^{\prime} \chi+v_{j}+\mu_{j}+\varepsilon_{i j t}$

The pathway specific DiD equation can be written as:

$s_{i j t}^{p}=\beta_{0}+\beta_{1}^{p} R_{t}+\beta_{2}^{p} T_{i}+\boldsymbol{\beta}_{3}^{p} R_{t} \times T_{i}+\beta_{4}^{p}$ multi $_{i}+x_{i j t}^{\prime p} \delta^{p}+m_{j t}^{\prime p} \chi^{p}+v_{j}^{p}+\mu_{t}^{p}+\varepsilon_{i j t}^{p}$

We performed the analysis at the individual patient's spell-level using a linear regression

model (i.e. linear probability model, because our dependent variable is dichotomous).

In equation (1), $s_{i j t}$ is the survival probability (the 30-day or 90-day after in-patient hospital admission while considering all patient pathways) of a patient-episode $i$, living in municipality $j$ at time $t ; R_{t}$ is defined as the reform, and $R_{t}=1$ indicates a post-CR time period of 2012-2013, while $R_{t}=0$ indicates the pre-CR time period of 2010-2011. $T_{i}$ indicates treatment status, where $T_{i}=1$ if patient belong to the intervention group (i.e. medical DRG group) and $T_{i}=0$ if patient belong to the surgical DRG (control group). multi $i_{i}$ is a dummy variable indicating whether a patient with multimorbidity. $\boldsymbol{P}_{\boldsymbol{i}}$ indicates a dummy variable on pathways, where $\mathrm{Ho}-\mathrm{H}-\mathrm{Ho}$ is considered as an omitted category. 
In equation (2) $s_{i j t}^{p}$ indicates patient pathway-specific survival probability (the 30-day or 90day). Al other terms included in the righthand side of equation (2) illustrate the same covariates as indicated in Equation (1) but the superscript $p$ indicates that they are the estimated coefficients for specific pathway. We performed the analysis at the individual patient's spell-level using a linear regression model (i.e. linear probability model, because our dependent variable is dichotomous). To control for observable patient differences, important patient-level observable characteristics that could influence survival probability. We include in particular, patients' socio-economic attributes and patient-level attributes reveal patients' needs and severity, as mentioned in Data and variables. To control for observable contextual differences given patient's residence, we also control for their time-variant municipal level observable characteristics (see Data and variables). In Equation (1), the vector $x$ includes patient-level attributes and vector $m$ includes municipality-level characteristics. The estimated interaction term, the DiD estimate, $\hat{\beta}_{3}$ (in Equation 1 ) measures the effect of CR reform while considering for all patient pathways and $\hat{\beta}_{3}^{p}$ (in Equation 2) indicates the effect of CR reform for specific patient pathway. Municipalities make decisions for their inhabitants that may not be observable in our data, but that may lead to changes in patients' health and social care use, and in turn their survival probability (i.e. the source of potential unobservable confounding factors). Given the heterogeneity amongst municipalities in the coverage of different health and social care services, in Equation (1) we include municipality unobservable fixed effects $v_{j}$, to capture municipality differences that are constant over time. To capture survival differences over time that are common to all municipalities we also include yearly fixed effects, $\mu_{t} . \varepsilon_{i j t}$ is the idiosyncratic error term.

There might be circumstances when the co-payment affects different types of hospital admission episodes differently because of the selection of patients. For example, financial incentives may not affect emergency admissions and in turn the survival probability but may influence planned admissions and the associated survival probability. To capture this sort of heterogeneity in the patient groups and to understand the mechanisms, we estimate separate regressions for emergency and planned admission episodes.

\section{Multimorbidity sub-analysis}


As mentioned above, it is important to study whether there is any differential relationship of the economic incentives for multimorbidity patients. To achieve this, we add additional interaction terms to examine any differential associations of multimorbidity status. Equation (1) can be rewritten (including all patient pathways) as:

$$
\begin{array}{ll}
s_{i j t}^{m}=\beta_{0}+\beta_{1}^{m} R_{t}+\beta_{2}^{m} T_{i}+\beta_{3}^{m} R_{t} \times T_{i}+\beta_{4}^{m} \text { multi }_{i}+\operatorname{multi}_{i}\left(\beta_{5}^{m} T_{i}+\beta_{6}^{m} R_{t}+\right. & \left.\boldsymbol{\beta}_{7}^{m} R_{t} \times T_{i}\right)+ \\
\beta_{4}^{m} \boldsymbol{P}_{i}+x_{i j t}^{\prime m} \delta^{p}+m_{j t}^{\prime m} \chi^{m}+v_{j}^{m}+\mu_{t}^{m}+\varepsilon_{i j t}^{m} & \text { (3) }
\end{array}
$$

The estimated coefficient for the triple interaction term (difference-in-differences-in-differences (DiDiD)) in Equation 3), $\hat{\beta}_{7}^{m}$ measures the differential relationships of the reform on multimorbidity patients compared with non-multimorbidity patients. We also estimate Equation (3) for alternative pathways and alternate admission types. Analogous to Equation (2), the pathway specific DiDiD equation can be written as:

$$
\begin{aligned}
s_{i j t}^{m^{p}}= & \beta_{0}+\beta_{1}^{m^{p}} R_{t}+\beta_{2}^{m^{p}} T_{i}+\beta_{3}^{m^{p}} R_{t} \times T_{i}+\beta_{4}^{m^{p}} m u l t i_{i}+\operatorname{multi}_{i}\left(\beta_{5}^{m^{p}} T_{i}+\beta_{6}^{m^{p}} R_{t}+\right. \\
& \left.\boldsymbol{\beta}_{7}^{m^{p}} R_{t} \times T_{i}\right)+x_{i j t}^{\prime m^{p}} \delta^{m^{p}}+m_{j t}^{\prime m^{p}} \chi^{m^{p}}+v_{j}^{m^{p}}+\mu_{t}^{m^{p}}+\varepsilon_{i j t}^{m^{p}}
\end{aligned}
$$

The estimated DiDiD coefficient $\hat{\beta}_{7}^{m}$ in Equation 4 measures the pathway specific differential effects of the reform on multimorbidity patients compared with non-multimorbidity patients.

\section{Parallel trends assumption}

A key assumption of the DiD analysis is that of parallel trends. This states in general terms that in the absence of intervention/reform, the average outcomes of the treatment group and the comparison groups are the same in the pre-intervention period [28]. This assumption has been tested graphically and statistically. To test the assumption statistically, we define the pre-reform period as 2010 (placebo pre-reform) and the post-reform period as 2011 (placebo post-reform) as a way 'artificially' to scrutinize the parallel trends assumption. This is tested by evaluating the significance of the coefficients $\hat{\beta}_{3}, \hat{\beta}_{3}^{p}, \hat{\beta}_{7}^{m}$ and $\hat{\beta}_{7}^{m^{p}}$ in regression models (1) (2) (3) and (4), respectively. Statistical insignificance of the coefficients implies that the parallel trends assumption is valid [29].

\section{Robustness checks}


To examine the robustness of our results, we performed a variety of analyses. The size of the Norwegian municipalities is diverse. There are many small municipalities in Norway with few inhabitants. The CR reform outcome may be different for smaller municipalities (or create noise in the estimation) than for larger ones. In the first set of robustness checks, we re-estimate (using Equations 1 and 2) our baseline DiD and DiDiD models (for all admissions; emergency and planned admissions separately) by dropping small municipalities (i.e. municipalities with total number of inhabitants less than 10,000). Additional DiDiD models are estimated by using an alternative definition of multimorbidity status of the patients, namely, if the number of chronic comorbidities is greater than or equal to 3 .

In the second set of robustness checks, we include all in-patient admissions (chronic and/or non-chronic) during our study period 2010-2013. First, using Equation (1) for this large sample, we estimate our baseline DiD models for all admissions, and emergency and planned admissions separately (because of a lack of information on multimorbidity status we cannot estimate the DiDiD models for this sample). Second, using the same sample and dropping small municipalities, we re-estimate the models (for all admissions, and for emergency and planned admissions separately) by dropping small municipalities (total number of inhabitants less than 10,000).

[1] Moreover, assessing the relationships with the 30-day and 90-day survival rates, using data on all inpatients' categories and all diagnoses in a regression specification may produce 'noise' because not all patients or diagnoses are equally important in terms of the CR.

[2] Patients often appear multiple times within the in-patient records since these are predominantly recorded at the episode level. Sometimes we use the terms "admission" and "episode" interchangeably.

[3] To check robustness of our results, we alternatively constructed multimorbidity status (multi=1) if the number of chronic comorbidities greater or equal to three.

[4] DRGs provide a flat per-discharge payment that varies based on diagnoses, severity, and procedures were performed. A standard year-specific monetary conversion factor, used to convert DRG weights into base payment rates for each DRG.

[5] This might not be an ideal instrument of patient's LOS but could mitigate the problem concerning patients with long LOS (or outliers).

\section{Results}

\section{Descriptive statistics}

Page $13 / 34$ 
Table 2 describes the distribution of patients for the medical DRGs and surgical DRGs, in both the preand post-reform periods. The survival rates (both the 30-day and 90-day) are comparable across the preand post-reform periods for all admissions, emergency admissions and planned admissions. Figure 1 also illustrates the 30-day and 90-day survival for medical and surgical diagnoses for all admissions and by admission types-emergency and planned over the years. Irrespective of admission types, survival probabilities are consistently lower for medical than surgical diagnoses, but survival probabilities are slightly increased in post-reform period for both the groups. Moreover, as expected, the survival rates (dependent variables) are lower for emergency admissions than for planned admissions for all groups of patients. We observe a slight decline in the share of admissions for multimorbidity patients (multi) between the pre- and post-reform period. This gives an indication that the overall patients' health on average maybe improved over time. The age and gender distributions are rather stable too. However, postreform, those aged 67-79 years (age79) constitute a larger share of both emergency and planned admissions than in the pre-reform period. The share of youngest patients is higher in the medical group than in the surgical group. The distribution of patients in the elderly age groups are comparable across these two groups. Regarding education level, the differences between groups and over periods are small.

The relative use of some of the pathways changed more profoundly. While the share of $\mathrm{H}_{0}-\mathrm{H}-\mathrm{H}_{\mathrm{o}}$ is rather stable, $\mathrm{H}_{\mathrm{o}}-\mathrm{H}-\mathrm{S}_{\mathrm{c}}$ doubled, driven mainly by changes in emergency admissions, from 4.9 per cent to 10.0 per cent. This increasing share is observed for both surgical (11.2 per cent to 20.0 per cent) and medical (3.9 per cent to 8.3 per cent) emergency patients (Table 2).

The survival probabilities are constant for patients following the pathways $\mathrm{H}_{\mathrm{o}}-\mathrm{H}-\mathrm{H}_{\mathrm{o}}$ but marginally increases for patients following the $\mathrm{H}_{\mathrm{o}}-\mathrm{H}-\mathrm{S}_{\mathrm{c}}$ and $\mathrm{H}_{\mathrm{o}}-\mathrm{H}-\mathrm{O}_{\mathrm{h}}$ pathways (Table 3). For the latter two pathways, the increasing rate in the survival probabilities are fairly higher for the 90-day survivals than the 30-day. Regarding the age distribution of patients, while there are few noticeable changes to the $\mathrm{H}_{\mathrm{o}}-\mathrm{H}-\mathrm{H}_{\mathrm{o}}$ pathway, there are interesting changes to the other two pathways. The $\mathrm{H}_{\mathrm{o}}-\mathrm{H}-\mathrm{S}_{\mathrm{c}}$ pathway has a noticeable reduction in the share of relatively young patients (age44). Those who are 45-66 years also constitute a smaller percentage in post-reform, a reduction of close to three percentage points. However, the shares are higher for the older groups of patients, with those who are 67-79 years and in particular those who are 80 years and older experiencing a change in share from 68.7 per cent to 69.9 per cent. There was also an increase within the age category $0-44$ years for the $\mathrm{H}_{\mathrm{o}}-\mathrm{H}-\mathrm{O}_{\mathrm{h}}$ pathway from 4.2 per cent to 5.2 per cent. For this same pathway there was an increase in share from 23.5 per cent to 25.4 per cent for the age category 45-66 years, and from 26.7 per cent to 28.7 per cent for the age category 67-79 years. However, the share of the oldest groups of patients, those 80 years and older, fell from 45.6 per cent to 40.6 per cent.

Tables 2 show that the mean episode specific LOS and the share of patient with higher than mean LOS days (i.e. LOS_M) change only moderately between pre- and post-reform period. However, separating the stays according to the pathways the patients follow, reveals a different finding. There are only small changes (both LOS and LOS_M) for patients taking the $\mathrm{H}_{\mathrm{o}}-\mathrm{H}-\mathrm{H}_{\mathrm{O}}$ pathway, but Table 3 shows that the average LOS for the $\mathrm{H}_{\mathrm{o}}-\mathrm{H}-\mathrm{S}_{\mathrm{c}}$ pathway changes from approx. 9.0 days to 7.5 days, a reduction of 
approximately 17 Per cent or 1.5 days on average. The share of patients with the higher than average LOS (LOS_M) is decreased by 1.5 percentage point. The LOS (and the LOS_M) is also reduced for patients taking the $\mathrm{H}_{\mathrm{o}}-\mathrm{H}-\mathrm{O}_{\mathrm{h}}$ pathway (from 8.1 to 6.5 days), a reduction of approximately 20 per cent, and LOS_M is decreased by 4.1 percentage point.

Most of the municipality attributes remain relatively constant between the pre- and post-reform periods. However, it is evident that the Phys_Inst attribute increased after the reform for both the intervention and comparison groups (Table 2) and within the pathways (Table 3 ).

\section{Analytical results}

\section{Main results and results by admission type for all chronic patients}

As discussed in the descriptive section of the paper, there are some noticeable differences between the pathways with respect to the age distribution of patients and the share of patients taking the different pathways pre- and post-reform. Thus, a more detailed analysis is required. The analytical main results for the 30-day and 90-day survival probabilities are presented in Tables 4. As indicated in the descriptive (also shows in Figure 1), the coefficients of the "reform" variable is found positively and significant associated with the survival probabilities, but the "treatment" coefficients are found negatively and significantly associated with survival probabilities. There are positive and significant $\mathrm{CR}$ associations (the reform*treat coefficients) with the 30-day survival rates for all admission episodes ( 0.36 per cent) and emergency episodes ( 0.68 per cent) analysed separately. The magnitude of the associations are also positive and significant, and comparatively higher for the 90-day survival probability for all admissions ( 0.58 per cent) and planned admissions ( 0.62 per cent). A positive but weak significant (at the 10 per cent level) relationship with the 90-day survival probability is observed for emergency admissions. For planned admissions, however, the relationship with the 30-day survival is statistically insignificant.

Table 4 also shows that relative to patients taking the $\mathrm{H}_{\mathrm{o}}-\mathrm{H}-\mathrm{H}_{\mathrm{O}}$ pathway (the omitted category), the other pathways have significantly lower survival rates (for both the 30-day and 90-day), as expected. Lower survival rates for patients going the $\mathrm{H}_{\mathrm{o}}-\mathrm{H}-\mathrm{O}_{\mathrm{h}}$ pathway are likely to be stronger than patients who take the $\mathrm{H}_{\mathrm{o}}-\mathrm{H}-\mathrm{S}_{\mathrm{c}}$ pathway.

We find opposite directions in the relationships between the LOS_M (i.e., whether LOS is greater than the average LOS) and different survival probabilities and admission types. The 30-day survival probability is positively and significantly associated with LOS_M for all and for emergency admissions, whereas the associations are negative and significant for the 90-day survival. However, for planned admissions LOS_M is negatively and significantly associated with both the 30 -day and 90 -day survival probabilities.

\section{Alternative pathways: overall results and results by admission type}

The path specific results from the analyses of the three most important pathways $\left(\mathrm{H}_{\mathrm{o}}-\mathrm{H}-\mathrm{H}_{\mathrm{O}}, \mathrm{H}_{\mathrm{o}}-\mathrm{H}-\mathrm{S}_{\mathrm{C}}\right.$ and $\mathrm{H}_{\mathrm{o}}-\mathrm{H}-\mathrm{S}_{\mathrm{c}}$ ) are reported in Table 5. Patients following the $\mathrm{H}_{\mathrm{o}}-\mathrm{H}-\mathrm{H}_{\mathrm{o}}$ pathway shows on average no significant 
associations for the survival probabilities. As we predicted at the onset, one could argue that this result is expected. Patients going home after hospitalization are on average likely to be rather healthier compared with patients discharged elsewhere. There is also a negative age effect because younger patients have higher survival rates than older ones.

Irrespective of alternative definition of the survival probabilities, patients following the $\mathrm{H}_{\mathrm{o}}-\mathrm{H}-\mathrm{S}_{\mathrm{c}}$ pathway experienced significant associations with their survival rates on average, but there is a substantial difference between emergency and planned admissions. For all admissions, the survival probabilities increase on average by 1.53 and 2.04 per cent for respectively 30-day and 90-day survival. Emergency admitted patients also experience a significant improvement in their survival rates (1.50 and 1.73 per cent for the 30-day and 90-day survival respectively). However, for planned admissions, the survival probabilities are negatively associated (7.48 and 13.62 per cent decrease in the survival rates for the 30day and 90-day survival respectively). The descriptive statistics in Table 3 show that more patients followed this pathway after reform and that the age distributions changed towards larger shares of older cohorts. The LOS also decreased quite substantially. Although not reported in Table 2, in our data we found that the average LOS decreased from 9.4 days to 7.4 days for emergency admissions but increased for planned admissions from 7.2 days to 9.1 days for patients following the $\mathrm{H}_{\mathrm{o}}-\mathrm{H}-\mathrm{S}_{\mathrm{c}}$ pathway. The reduced survival rates for planned admissions indicate that the chronic and multimorbidity patients are older and frailer than in the pre-reform period, while emergency patients are younger and stronger leading to an increase in their survival rates for this pathway. We hypothesized that the CR is likely to be the cause of this shift in the distribution of patients.

The survival rates (both the 30 and 90-day) for all and emergency admitted patients following the $\mathrm{H}_{\mathrm{O}}-\mathrm{H}$ $\mathrm{O}_{\mathrm{h}}$ pathway are also positively and significantly associated with survival. There is no significant association for planned admissions for the 30 -day but a positive and significant association holds for the 90-day survival rate.

\section{Multimorbidity subgroup: overall results and results by admission type and pathways}

Using Equation (3) for multimorbidity patients, the summary results (analogous to those in Table 4) are reported in the first row of Table 6 (i.e.). For both the 30-day and 90-day survival probabilities, no significant associations are observed for all admissions and alternative admission types, emergency admissions or planned admissions, for these multimorbidity patients.

Table 6 also shows the relationship between the CR and survival probability within the pathways (i.e. for multimorbidity patients (analogous to those in Table 5). For all admissions, we find a weak negative and significant association (at the 10 per cent level) with the 30-day survival probability for the multimorbidity patients following the $\mathrm{H}_{\mathrm{o}}-\mathrm{H}-\mathrm{H}_{\mathrm{o}}$ pathway, and this negative and significant relationship (at the 5 per cent level) with survival probability is also observed for planned admissions for patients following this pathway. However, for emergency admissions we find a positive and significant association with the 90day survival probability for patient following this pathway. For the patients following the $\mathrm{H}_{\mathrm{o}}-\mathrm{H}-\mathrm{S}_{\mathrm{c}}$ 
pathway, although we find positive and insignificant associations with the 30 -day survival for all and emergency patients, the relationships are positively and significantly associated with the 90-day survival probability. For planned admissions, we find negative but insignificant associations with survival probabilities for the multimorbidity patients following the $\mathrm{H}_{\mathrm{o}}-\mathrm{H}-\mathrm{S}_{\mathrm{c}}$ pathway. Negative associations are also observed for all admissions, emergency and planned, for patients following the $\mathrm{H}_{\mathrm{o}}-\mathrm{H}-\mathrm{O}_{\mathrm{h}}$ pathway. However, all coefficients are insignificant. Overall, these results indicate that the positive associations with the 90-day survivals rates and the CR-reform on multimorbidity patients is pertinent for the $\mathrm{H}_{\mathrm{o}}-\mathrm{H}-\mathrm{H}_{\mathrm{o}}$ (0.87 per cent) and $\mathrm{H}_{\mathrm{o}}-\mathrm{H}-\mathrm{S}_{\mathrm{C}}$ (3.57 per cent) pathways for the emergency patients. For the $\mathrm{H}_{\mathrm{o}}-\mathrm{H}-\mathrm{H}_{\mathrm{o}}$ pathway and planned patients such an association is negative ( 0.58 per cent) with the 30 -day survival rates.

\section{Testing the parallel trends assumption}

The statistical tests for placebo reform effects (test of the parallel trends assumption) for chronic patients (DiD estimates) and for the multimorbidity subgroup results (DiDiD estimates) are presented in Table 7. Our graphical (Figure. 1) and statistical results are not entirely convincing in supporting the parallel trends assumption for all alternative admissions and pathways.

Nevertheless, for our important patient group, that is, patients following the $\mathrm{H}_{\mathrm{o}}-\mathrm{H}-\mathrm{S}_{\mathrm{c}}$ pathway, the placebo reform effects (DiD estimates) are found to be insignificant for all admissions and emergency admissions and for both survival indicators $₫ 30$-day and 90-day. These results imply that the positive $\mathrm{CR}$ effects on survival rates for this patient pathway may not be biased.

The placebo DiDiD estimate for planned admissions is insignificant for the multimorbidity subgroup patients following the $\mathrm{H}_{0}-\mathrm{H}-\mathrm{H}_{\mathrm{o}}$ pathway (for the 30-day survival), which implies that the negative $\mathrm{CR}$ effects (reported in Table 6) on the 30-day survival rates for multimorbidity patients (planned admissions) is not biased for this pathway. Analogously, the placebo DiDiD estimate for emergency admissions for both survival indicators is insignificant for the multimorbidity patients following the $\mathrm{H}_{\mathrm{O}}-\mathrm{H}-$ $S_{c}$ pathway, which suggests that the positive $C R$ effects (reported in Table 6) on the 90-day survival rates for multimorbidity patients (emergency admissions) is not also biased for the $\mathrm{H}_{\mathrm{o}}-\mathrm{H}-\mathrm{S}_{\mathrm{c}}$ pathway.

Notice that for all other placebo DiD and DiDiD estimates (reported in Table 7), we do not find any positive and significant relationships with any of the alternative admissions and pathways. Intuitively, this result suggests that the pre-reform trend in the survival rate was either 'negative' or 'no trend', but was not 'positive'.

\section{Robustness checks}

Table 8 presents the DiD and DiDiD estimates for chronic and multimorbidity subgroup patients with small municipalities omitted. Compared with the DiD coefficients reported in Table 4, we find positive and significant associations with the CR (and larger) for all admissions $(0.50$ per cent and 0.68 per cent for the 30-day and 90-day survival respectively) and emergency admission ( 0.89 per cent and 0.63 per cent 
for the 30-day and 90-day survival respectively) and no association for planned admissions for the 30day survival but positive association with the 90 -day survival ( 0.54 per cent). Analogously, for this restricted sample, as before, null effect is observed for the $\mathrm{H}_{\mathrm{o}}-\mathrm{H}-\mathrm{H}_{\mathrm{o}}$ pathway; positive and significant (rather weak) associations are observed for all admissions for the two other pathways (see Table 5)[1].

For this restricted sample, our DiDiD estimates for multimorbidity subgroup patients also produce similar results to those reported in Table 6. Moreover, an alternative definition of multimorbidity status of the patients, that is, if the number of chronic comorbidities is greater than or equal to 3 , yields similar results.

Using Equations (1 and 2), we further examine the CR effects for all in-patient admissions (chronic and/or non-chronic patients) during the study period 2010-2013. For this vast number of in-patient admissions $(\mathrm{N}=1,902,564)$, for both survival variables, we also find positive and significant $\mathrm{CR}$ effects for all admissions but with a comparatively smaller survival probabilities $(0.16$ per cent and 0.35 per cent for the 30-day and 90-day respectively) and do not find any significant effect for emergency and planned admission separately[2]. However, we find a small negative and significant association with the 30-day survival ( -0.10 per cent but no significant association with the 90-day survival rate) for the $\mathrm{H}_{\mathrm{o}}-\mathrm{H}-\mathrm{H}_{\mathrm{o}}$ pathway for this sample. As before, a positive and significant association is observed for all admissions for the $\mathrm{H}_{\mathrm{o}}-\mathrm{H}-\mathrm{O}_{\mathrm{h}}$ pathway; but no significant relationship is observed for all admissions for the $\mathrm{H}_{\mathrm{o}}-\mathrm{H}-\mathrm{S}_{\mathrm{C}}$ pathway (not reported here but results can be available upon request). As a further robustness check, we repeat the same analyses for all in-patient admissions, but excluding small municipalities, and obtain similar results as those when including all municipalities.

[1] Moreover, we have also estimated the models excluding municipality-level time-varying characteristics, and find similar results (in respect of the magnitude of coefficients and their directions) as reported in Tables 4 \& 5. In particular, positive and significant CR effects for all admissions, emergency admission, and null effect for planned admissions .

[2] For this large sample, in our data we do not have information about the patients' multimorbidity status.

\section{Discussion}

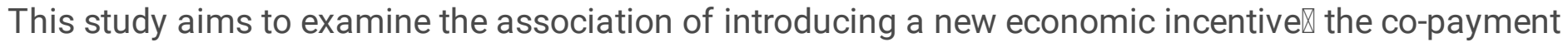
scheme $\mathbb{Z}$ with the 30-day and 90-day survival probabilities after hospitalization for chronic and multimorbidity patients. This study hypothesizes that new economic incentives - through changes in the distribution of patients allocated to the specific pathways compared to the pre-Coordination Reform (CR) 
situation could influence survival probabilities. To add to our understanding of underlying mechanisms behind the association of the CR on survival, the patient pathways among different health care and social care providers are modelled explicitly. In our subgroup analysis, we examine differential effects by alternative in-patient admissions as well.

The descriptive results show that the survival probabilities are slightly increased for both medical and surgical groups in the post reform period. The distribution of the sampled patients by age, gender and education does not change between the pre- and post-reform periods. The distributions of the patients following the different pathways are more or less similar pre- and post-CR. The notable differences are observed for one specific pathway: patients coming from home and discharged to social care institution after hospitalization $\left(\mathrm{H}_{\mathrm{o}}-\mathrm{H}-\mathrm{S}_{\mathrm{c}}\right)$. The noteworthy differences from the pre-reform period are: (i) a near doubling of the share of patients taking this path, (ii) a decline in the share of relatively young patients ( $<67$ years of age) following this path, and (iii) a sharp decline in average LOS at hospital for patients taking this path.

Our difference-in-differences main results show that the survival probability for patients with chronic conditions is significantly and positively associated with the $C R$. The overall findings of a positive association are stable across the majority of robustness checks. After analysing emergency and planned admissions separately, however, we find that the change in the survival probability is significant and positive for emergency admissions only. There is no significant change for planned admissions.

As we predicted at the onset, patient pathway-specific analyses offer some diverse results. We find no significant difference for patients that are admitted to hospital from home and return home $\left(\mathrm{H}_{\mathrm{o}}-\mathrm{H}-\mathrm{H}_{\mathrm{o}}\right)$, the largest group of patients. We predicted that the patients following this pathway are likely to be comparable to the pre-reform situation in terms of probability of receiving formal and/or informal care given at home. Unfortunately, we do not have data on neither formal care intensity nor informal care given after hospitalization, which would allow us to control for the changes in intensity of both formal and informal care. We do find positive and significant associations with survival for emergency patients for two specific pathways; patients coming from home and discharged to either a social care institution or to another health care institution after hospitalization $\left(\mathrm{H}_{\mathrm{o}}-\mathrm{H}-\mathrm{S}_{\mathrm{C}}\right.$ and $\left.\mathrm{H}_{\mathrm{o}}-\mathrm{H}-\mathrm{O}_{\mathrm{h}}\right)$. The former result potentially contradicts the results reported in Bruvik et al. (2017), as we noted in the introduction. They find, based on a case study, that the number of patients who died in the nursing home after hospitalization doubled following the $\mathrm{CR}$, while procedures and staffing were unchanged between preand post-CR. They report, as we do, that the distribution of patients changes, particularly the age distribution: patients were older pre-reform than post-reform. Bruvik et al. [14]concluded that shorter hospitalization periods leading to an increase in the number of patients transferred to nursing homes must be a result of a path shifting mechanism: patients that stay longer in hospital would be in better health when discharged thus avoiding the need to be admitted to social care institutions. As far as we know, Bruvik et al. [14] do not distinguish between patients admitted to hospital from home or from a social care institution, which would potentially be an indicator of health status upon admission. Their argument is that patients are frailer when discharged sooner, thus, the survival rates for the patients will 
drop. We argue that through better coordination between hospital in charge of treatment and nursing home or "follow-up" hospital after discharge, the new economic incentives may have positively influenced the survival probabilities for patients following these paths. Nevertheless, we find that for planned admissions of patients coming from home and subsequently discharged to social care institutions (a small number of patients), the survival probabilities (both 30-day and 90-day) are reduced significantly. Multimorbidity subgroup analysis shows that this negative survival relationship is consistent across all pathways for the 30-day survival, and most evidently for the patients following the $\mathrm{H}_{\mathrm{o}}-\mathrm{H}-\mathrm{O}_{\mathrm{h}}$ pathway. However, based on our analysis we cannot support the notion that the $\mathrm{CR}$ led to a reduction in survival rates more generally, at least not for all chronic patients.

Theoretically, we argue that the new economic incentives may have countervailing effects. It could be the case that the co-payment system might induce selection of patients, i.e. for a given level of effort and quality a municipality could be induced to hospitalize the relatively more demanding patients while taking care of the less demanding patients. Thus, one could argue that the co-payment system might lead to a situation in which hospitals would have to take care of the comparatively more sick or frail patients. The fact that the average LOS is reduced quite substantially may at first contradict the selection hypothesis, i.e. if patients were more ill, they would be expected to stay longer in hospital. However, the penalty scheme may also come into play. The penalty scheme allows hospitals to unilaterally decide the discharge date, at least in principle, which may have induced hospitals to bring forward discharge dates compared to the pre-reform period. First, the understanding that some patient groups did stay too long in hospital in the pre-reform period from a medical perspective while the hospitals now have an economic incentive to discharge patients sooner. Overall, our results indicate that the $\mathrm{CR}$ has influenced municipalities and hospitals to change both the number of patients following the different pathways and the distribution of patients. It is likely that the new economic incentives have played a role.

The study has a number of weaknesses. A concern concerning the estimation is the parallel trends assumption on which the DiD approach relies. Although we controlled for the patient and municipal level attributes, and municipality fixed-effects, our main weakness is that we have only limited data points both pre- and post-CR to validate whether this assumption is well satisfied. Our statistical evidence is not totally convincing for comparable pre-intervention trends for all alternative admissions and pathways, except for the $\mathrm{H}_{\mathrm{o}}-\mathrm{H}-\mathrm{S}_{\mathrm{c}}$ pathway. However, our placebo reform estimates (Table 7) suggests that the prereform trend in the survival rate was either 'negative' or 'no trend' but was not 'positive'.

An issue we briefly mentioned in the introduction is that the CR introduced several policy instruments simultaneously. Although municipalities could have implemented emergency bed capacity (EBC) 'at will' as long as they had met the deadline [13], the interplay between the co-payment scheme and the use of discharge fees in relation to delay from hospitals are not clear-cut. Nevertheless, Ambugo and Hagen [12] found no statistically significant moderated effects of the discharge fees on the municipal level death rates and readmissions across the patient groups, except for patients with stroke. Moreover, we have tried to disentangle one of the links by analysing EBC and non-EBC municipalities separately. We do not find 
any noteworthy differences in our main results reported here for patients from municipalities with EBC and those without.

\section{Conclusions}

Three concluding remarks can be made. First, on average the majority of chronic patients experience either a positive association, or experience a status quo, in terms of survival probability following the introduction of the CR. Multimorbidity subgroup analysis shows no significant association with survival probabilities for all chronic patients. Second, the survival rates for patients with chronic conditions and multimorbidity depend both on their admission type and on the specific pathway they follow. In general, the positive survival relationship with the $\mathrm{CR}$ is consistent mainly for the Home-Hospital-Social care $\left(\mathrm{H}_{\mathrm{o}}\right.$ $\mathrm{H}-\mathrm{S}_{\mathrm{c}}$ ) patient pathway. Moreover, the $\mathrm{CR}$ seems to have altered the relative importance of the specific pathways. Therefore, we accomplish that without modelling pathways explicitly, one may overlook important changes following the CR. Future policy evaluation studies in any pertinent context should consider these aspects. Finally, emergency admissions represent the largest group of chronic and multimorbidity patients and this group has increased survival rates for two specific pathways. However, the survival probability for a smaller group of patients, those with planned admissions, decreased.

Policy recommendations must be made with some reservations. There is no consensus in the economic literature concerning the efficacy, applicability and optimal implementation of alternative incentive schemes under different institutional arrangements. Obviously, thorough theoretical and empirical studies are required to make a valid assessment of any new incentive schemes. It would be useful to study whether the extended patients' lives (benefit) are clinically relevant or large enough to counterbalance the associated social cost with the reform. By estimating the cost and benefits of the CR across pathways and alternate admissions, in future a comprehensive welfare analysis would be beneficial.

\section{Abbreviations}

CR: Coordination Reform

GP: General Practitioner

DRG: Diagnoses-Related Group

LOS: Length of Stay

COPD: Chronic Obstructive Pulmonary Disease

EBC: Emergency Bed Capacity

OECD: Organisation for Economic Co-operation and Development

DiD: Difference-in-Differences

Page 21/34 
$\mathrm{H}_{\mathrm{O}}-\mathrm{H}-\mathrm{H}_{\mathrm{O}}$ : Home-Hospital-Home

$\mathrm{H}_{\mathrm{o}}-\mathrm{H}-\mathrm{S}_{\mathrm{C}}$ : Home-Hospital-Social Care Institution

$\mathrm{H}_{\mathrm{o}}-\mathrm{H}-\mathrm{O}_{\mathrm{h}}$ : Home/and or Social care to Hospital to another Hospital

NPR: Norwegian Patient Registry

KOSTRA: KOmmune-STat-RApportering (Municipality-State-Reporting)

ICD: International Classification of Diseases

DiDiD: Difference-in-Differences-in-Differences

\section{Declarations}

\section{Ethics approval and consent to participate}

Not applicable since all data is anonymous.

\section{Consent for publication}

Not applicable.

\section{Availability of data and materials}

The data used in this study are available from The Norwegian Directorate of Health (www.helsedirektoratet.no/) and Statistics Norway (www.ssb.no), but restrictions apply to the availability of these data, which were used under licence for the current study, and so are not publicly available. However, data are available from the authors upon reasonable request and with included permission from The Norwegian Directorate of Health, Statistics Norway and Norwegian Data Protection Authority.

\section{Competing interests}

The authors declare that they have no competing interests.

\section{Funding}

The SELFIE (Sustainable intEgrated care modeLs for multi-morbidity: delivery, Flnancing and performancE) project has received funding from the European Union's Horizon 2020 research and innovation programme under grant agreement No 634288. The content of this work reflects only the SELFIE groups' views and the European Commission is not liable for any use that may be made of the information contained herein. The funding body had no role in the design of the study; in the collection, analysis, and interpretation of data; and in the writing of the manuscript. 


\section{Authors' contributions}

MKI and JEA conceived this study. MKI and EK designed the analysis plan. MKI conducted the analysis. MKI and EK wrote the first draft of the paper, and all authors revised the paper and approved the final version.

\section{Acknowledgements}

We would like to thank two anonymous referees for their constructive comments and suggestions, which have improved the paper. An earlier version of this manuscript was presented at the $6^{\text {th }}$ SELFIE Steering Committee Meeting 2018, Budapest, Hungary; the $12^{\text {th }}$ European Health Economics Association (EuHEA) Conference 2018, Maastricht, the Netherlands; the $40^{\text {th }}$ Nordic Health Economics Study Group (NHESG) conference 2019, Reykjavik, Iceland. The authors thank Tor Helge Holmås, Matt Sutton, Cecilia Dahlgren and other participants of the workshop and conferences for their comments and suggestions.

\section{References}

1. Yach D, Hawkes C, Gould CL, Hofman KJ. The Global Burden of Chronic Diseases: Overcoming Impediments to Prevention and Control. JAMA. 2004;291(21):2616-2622. doi:10.1001/jama.291.21.2616

2. Abegunde DO, Mathers CD, Adam T, Ortegon M, Strong K. The burden and costs of chronic diseases in low-income and middle-income countries. Lancet. 2007;370(9603):1929-1938. doi:10.1016/S0140-6736(07)61696-1.

3. Buttorff C., Ruder T., Bauman M. Multiple Chronic Conditions in the United States. RAND Corporation; Santa Monica, CA: 2017. https://www.rand.org/pubs/tools/TL221.html. Accessed 11 June 2019.

4. Centers for Disease Control and Prevention (CDC). Health and Economic Costs of Chronic Diseases 2019.https://www.cdc.gov/chronicdisease/about/costs/index.htm\#ref1. Accessed 11 June 2019.

5. Busse, Reinhard, Blümel, Miriam, Scheller-Kreinsen, David. et al. Tackling chronic disease in Europe: strategies, interventions and challenges. World Health Organization. Regional Office for Europe. 2010 https://apps.who.int/iris/handle/10665/326484. ISBN 9789289041928. Accessed 12 June 2019.

6. Barnett K, Mercer SW, Norbury M, Watt G, Wyke S, Guthrie B. Epidemiology of multimorbidity and implications for health care, research, and medical education: a cross-sectional study. Lancet, 2012;380:37-43

7. Orueta JF, García-Álvarez A, García-Goñi M, Paolucci F, Nuño-Solinís R. Prevalence and costs of multimorbidity by deprivation levels in the basque country: a population based study using health administrative databases. PLoS One. 2014;9(2):e89787. doi:10.1371/journal.pone.0089787

8. Quinn, K.The Eight basic Payment Methods in Health care. Ann Intern Med.2015;163:300-306. doi:10.7326/M14-2784

9. Stokes, J. Struckmann, V., Kristensen, S.R., et al., 2018. Towards incentivising integration: A typology of payments for integrated care. Health Policy,122, pp.963-969. 
https://doi.org/10.1016/j.healthpol.2018.07.003.

10. White Paper: White Paper No. 47 (2008-2009). Coordination Reform, Ministry of Health and Care, Oslo 2008. https://www.regjeringen.no/contentassets/d4f0e16ad32e4bbd8d8ab5c21445a5dc/engb/pdfs/stm200820090047000en_pdfs.pdf. Accessed 10 May 2019.

11. Abelsen B, Gaski M, Nødland SI, Stephansen A. Samhandlingsreformens konsekvenser for det kommunale pleie-og omsorgstilbudet. Stavanger: International Research Institute of Stavanger (IRIS); 2014.

12. Askildsen, J.E., Holmås, T.H., Kaarbøe, O., Monstad, K, 2016. Evaluering av kommunal medfinansiering. Tidsskrift for omsorgsforskning, 2, pp.135-14.

13. Melberg, H.O., Hagen T.P., 2016. Liggetider og reinnleggelser i somatiske sykehus før og etter Samhandlingsreformen. Tidsskrift for omsorgsforskning, 2, pp.143-158.

14. Ambugo EA, Hagen TP. Effects of introducing a fee for inpatient overstays on the rate of death and readmissions across municipalities in Norway. Soc Sci Med. 2019;230:309-317. doi:10.1016/j.socscimed.2019.04.006

15. Islam MK, Kjerstad E. Co-ordination of health care: the case of hospital emergency admissions. Eur J Health Econ. 2019;20(4):525-541. doi:10.1007/s10198-018-1015-x

16. Bruvik, F., Dragese, J. Abrahamsen, J.F, 2017. From hospitals to nursing homes - the consequences of the Care Coordination Reform. Sykepleien Forskning, 12 (60613).

17. Gautun, H. Syse, A. Samhandlingsreformen: Hvordan tar de kommunale helse -og omsorgstjenestene i mot det $\varnothing$ kte antallet pasienter som skrives ut fra sykehusene? (NOVA Rapport 8/13). http://www.hioa.no/Om-OsloMet/Senter-for-velferds-ogarbeidslivsforskning/NOVA/Publikasjonar/Rapporter/2013/Samhandlingsreformen Accessed 10 June 2019.

18. Meacock R, Anselmi L, Kristensen SR, Doran T, Sutton M. Higher mortality rates amongst emergency patients admitted to hospital at weekends reflect a lower probability of admission. J Health Serv Res Policy. 2017;22(1):12-19. doi:10.1177/1355819616649630.

19. Kahlon S, Pederson J, Majumdar SR, et al. Association between frailty and 30-day outcomes after discharge from hospital. CMAJ. 2015;187(11):799-804. doi:10.1503/cmaj.150100.

20. Monkerud, L. C., \& Tjerbo, T. The effects of the Norwegian Coordination Reform on the use of rehabilitation services: panel data analyses of service use, 2010 to 2013. BMC Health Services Research, 2016, 16(a), 353. https://doi.org/10.1186/s12913-016-1564-6

21. Cashin, C, Chi, Y-Ling, Smith, P, Borowitz, M, Thomson, S (eds.). Paying for performance in healthcare: implications for health system performance and accountability. European Observatory on Health Systems and Policies Series. World Health Organization, Open University Press, Buckingham, UK, 2014.

22. Milstein R.,Schreyogg J, 2016. Pay for performance in the inpatient sector: A review of 34 P4P programs in 14 OECD countries. Health Policy, 2016, 120(10), pp. 1125-1140. https://doi.org/10.1016/j.healthpol.2016.08.009. 
23. Borzecki, A.M., Christiansen, C.L., Chew, P., Loveland, S., Rosen, A.K.Comparison of in-hospital versus 30-day mortality assessments for selected medical conditions. Medical Care, 2010, 48(12):pp.111721. DOI: 10.1097/MLR.0b013e3181ef9d53.

24. OECD, Health at a Glance 2017: OECD Indicators, OECD Publishing, Paris. 2017. http://dx.doi.org/10.1787/health_glance-2017-en. Accessed 25 June 2020.

25. Hassani S, Lindman AS, Kristoffersen DT, Tomic O, Helgeland J. 30-Day Survival Probabilities as a Quality Indicator for Norwegian Hospitals: Data Management and Analysis. PLoS One. 2015;10(9). doi:10.1371/journal.pone.0136547.

26. Tonelli, M., Wiebe, N., Fortin, M. et al. Methods for identifying 30 chronic conditions: application to administrative data. BMC Med Inform Decis Mak, 2016 15:31. https://doi.org/10.1186/s12911-0150155-5p.31.

27. Islam, M.K., Kjerstad, E. The Ambiguous Effect of GP Competition: The Case of Hospital Admissions. Health Economics, 2017, 26(12), pp.1483-1504. https://doi.org/10.1002/hec.3439

28. Angrist J, Pischke J-S. Mostly Harmless Econometrics: An Empiricist's Companion. Princeton University Press; 2009.

29. Dimick, J.B., Ryan, A.M.. Methods for evaluating changes in Health care policy: The difference-indifferences approach. JAMA guide to statistics and methods. JAMA, 2014, 312(22):pp. 2401-2.

\section{Tables}

Table 1: Variables' name and description 


\begin{tabular}{|c|c|}
\hline Name & Definition \\
\hline \multicolumn{2}{|r|}{ Patient-level covariates } \\
\hline surv_30 & Survival probability after 30 days of hospital in-patient admission \\
\hline surv_90 & Survival probability after 90 days of hospital in-patient admission \\
\hline Multi & $\begin{array}{l}\text { Equal to } 1 \text {; if the number of chronic comorbidities is greater than or equal to } 2 \text {; } \\
\text { Equal to } 0 \text {; if the number of chronic comorbidities is less than } 2\end{array}$ \\
\hline age44 & Age $<45$ years \\
\hline age66 & Age between 45 and 66 years \\
\hline age79 & Age between 67 and 79 years \\
\hline age80 & Age 80 years and older \\
\hline Male & Male $=1 ;$ Female $=0$ \\
\hline edu1 & Seven years of primary school or less \\
\hline edu2 & High school, intermediate school, vocational school, 1-2 years of high school \\
\hline edu3 & $\begin{array}{l}\text { University qualifying examination/junior college/University or other post- } \\
\text { secondary education or less/more than four years of university/college }\end{array}$ \\
\hline $\mathrm{H}_{\mathrm{O}}-\mathrm{H}-\mathrm{H}_{\mathrm{O}}$ & If the patient goes from home to hospital and discharged to home from hospital \\
\hline $\mathrm{H}_{\mathrm{O}}-\mathrm{H}-\mathrm{S}_{\mathrm{C}}$ & $\begin{array}{l}\text { If the patient goes from home to hospital and discharged to social care from } \\
\text { hospital }\end{array}$ \\
\hline $\mathrm{H}_{\mathrm{o}}-\mathrm{H}-\mathrm{O}_{\mathrm{h}}$ & $\begin{array}{l}\text { If the patient goes from home to hospital and discharged to other health care } \\
\text { institution from hospital }\end{array}$ \\
\hline $\mathrm{S}_{\mathrm{c}}-\mathrm{H}-\mathrm{S}_{\mathrm{c}}$ & $\begin{array}{l}\text { If the patient goes from social care to hospital and discharged to social care } \\
\text { from hospital }\end{array}$ \\
\hline $\mathrm{O}_{\mathrm{h}}-\mathrm{H}-\mathrm{O}_{\mathrm{h}}$ & $\begin{array}{l}\text { If patient goes from other health care institution to hospital and discharged to } \\
\text { other health care institution from hospital }\end{array}$ \\
\hline $\mathrm{S}_{\mathrm{C}}-\mathrm{H}-\mathrm{O}_{\mathrm{h}}$ & $\begin{array}{l}\text { If the patient goes from social care institution to hospital and discharged to } \\
\text { other health care institution from hospital }\end{array}$ \\
\hline hrg_log & Log of DRG prices (yearly-adjusted) \\
\hline LOS & Episode specific length of in-patient hospital stays (in days) \\
\hline LOS_M & $\begin{array}{l}\text { Equal to 1; if patient's LOS is greater than average yearly LOS calculated by } \\
\text { each hospital for each DRGs }\end{array}$ \\
\hline
\end{tabular}

\section{Municipality-level covariates}

\begin{tabular}{l|l}
\hline Percap_GP & Per capita general practitioner (GP) at municipality \\
\hline GP_open & Share of GPs with an open list at the municipality \\
\hline Phys_Inst & Physician time per week per resident in a nursing home (in hours) \\
\hline Inst_resi80 & Share of residents living in an institution of age 80 years or over \\
\hline Ins__80 & Share of inhabitants of 80 years or over that live in an institution \\
\hline Liv_alone & $\begin{array}{l}\text { Share of living-alone users in a municipality that do not live in an institution } \\
\text { (living at home) }\end{array}$ \\
\hline
\end{tabular}

Table 2: Descriptive statistics on the distribution of patients with chronic conditions pre- and post-reform by surgical and medical DRGs, and by admission type 


\begin{tabular}{|c|c|c|c|c|c|c|c|c|c|c|c|c|}
\hline \multirow[t]{3}{*}{ es } & \multicolumn{4}{|c|}{ All admissions $(\mathrm{N}=547,101)$} & \multicolumn{4}{|c|}{$\begin{array}{l}\text { Emergency admissions } \\
(\mathrm{N}=435,465)\end{array}$} & \multicolumn{4}{|c|}{ Planned admissions $(\mathrm{N}=111,636)$} \\
\hline & \multicolumn{2}{|c|}{ Surgical DRGs } & \multicolumn{2}{|c|}{ Medical DRGs } & \multicolumn{2}{|c|}{ Surgical DRGs } & \multicolumn{2}{|c|}{ Medical DRGs } & \multicolumn{2}{|c|}{ Surgical DRGs } & \multicolumn{2}{|c|}{ Medical DRGs } \\
\hline & $\begin{array}{l}\text { Pre-Reform } \\
(\mathrm{n}=60,670)\end{array}$ & $\begin{array}{c}\text { Post- } \\
\text { reform } \\
(\mathrm{n}=63,327)\end{array}$ & $\begin{array}{l}\text { Pre-Reform } \\
(\mathrm{n}=211,146)\end{array}$ & $\begin{array}{l}\text { Post-reform } \\
(\mathrm{n}=211,958)\end{array}$ & $\begin{array}{l}\text { Pre-Reform } \\
(\mathrm{n}=31,510)\end{array}$ & $\begin{array}{c}\text { Post- } \\
\text { reform } \\
(\mathrm{n}=31,627)\end{array}$ & $\begin{array}{l}\text { Pre-Reform } \\
(\mathrm{n}=186,177)\end{array}$ & $\begin{array}{l}\text { Post-reform } \\
(\mathrm{n}=186,151)\end{array}$ & $\begin{array}{l}\text { Pre-Reform } \\
(\mathrm{n}=29,160)\end{array}$ & $\begin{array}{c}\text { Post- } \\
\text { reform } \\
(\mathrm{n}=31,700)\end{array}$ & $\begin{array}{l}\text { Pre-Reform } \\
(\mathrm{n}=24,969)\end{array}$ & $\begin{array}{c}\text { Post- } \\
\text { reform } \\
(\mathrm{n}=25,807)\end{array}$ \\
\hline & $\begin{array}{c}\text { Mean } \\
\text { (Std. Dev.) }\end{array}$ & $\begin{array}{c}\text { Mean } \\
\text { (Std. Dev.) }\end{array}$ & $\begin{array}{c}\text { Mean } \\
\text { (Std. Dev.) }\end{array}$ & $\begin{array}{c}\text { Mean } \\
\text { (Std. Dev.) }\end{array}$ & $\begin{array}{c}\text { Mean } \\
\text { (Std. Dev.) }\end{array}$ & $\begin{array}{c}\text { Mean } \\
\text { (Std. Dev.) } \\
\end{array}$ & $\begin{array}{c}\text { Mean } \\
\text { (Std. Dev.) }\end{array}$ & $\begin{array}{c}\text { Mean } \\
\text { (Std. Dev.) }\end{array}$ & $\begin{array}{c}\text { Mean } \\
\text { (Std. Dev.) }\end{array}$ & $\begin{array}{c}\text { Mean } \\
\text { (Std. Dev.) } \\
\end{array}$ & $\begin{array}{c}\text { Mean } \\
\text { (Std. Dev.) }\end{array}$ & $\begin{array}{c}\text { Mean } \\
\text { (Std. Dev.) }\end{array}$ \\
\hline & $\begin{array}{r}0.968 \\
(0.177) \\
\end{array}$ & $\begin{array}{r}0.971 \\
(0.169) \\
\end{array}$ & $\begin{array}{c}0.941 \\
(0.236) \\
\end{array}$ & $\begin{array}{c}0.942 \\
(0.233) \\
\end{array}$ & $\begin{array}{c}0.942 \\
(0.234) \\
\end{array}$ & $\begin{array}{c}0.946 \\
(0.226) \\
\end{array}$ & $\begin{array}{c}0.936 \\
(0.244) \\
\end{array}$ & $\begin{array}{r}0.938 \\
(0.242) \\
\end{array}$ & $\begin{array}{c}0.995 \\
(0.070) \\
\end{array}$ & $\begin{array}{c}0.995 \\
(0.068) \\
\end{array}$ & $\begin{array}{r}0.974 \\
(0.161) \\
\end{array}$ & $\begin{array}{r}0.974 \\
(0.159) \\
\end{array}$ \\
\hline & $\begin{array}{c}0.942 \\
(0.234) \\
\end{array}$ & $\begin{array}{c}0.951 \\
(0.219) \\
\end{array}$ & $\begin{array}{c}0.895 \\
(0.307) \\
\end{array}$ & $\begin{array}{c}0.902 \\
(0.298) \\
\end{array}$ & $\begin{array}{c}0.900 \\
(0.300) \\
\end{array}$ & $\begin{array}{r}0.913 \\
(0.282) \\
\end{array}$ & $\begin{array}{c}0.890 \\
(0.313) \\
\end{array}$ & $\begin{array}{c}0.896 \\
(0.305) \\
\end{array}$ & $\begin{array}{r}0.988 \\
(0.109) \\
\end{array}$ & $\begin{array}{c}0.989 \\
(0.102) \\
\end{array}$ & $\begin{array}{c}0.932 \\
(0.252) \\
\end{array}$ & $\begin{array}{c}0.939 \\
(0.240) \\
\end{array}$ \\
\hline & $\begin{array}{c}0.325 \\
(0.468) \\
\end{array}$ & $\begin{array}{c}0.306 \\
(0.461) \\
\end{array}$ & $\begin{array}{c}0.426 \\
(0.495) \\
\end{array}$ & $\begin{array}{c}0.404 \\
(0.491) \\
\end{array}$ & $\begin{array}{c}0.374 \\
(0.484) \\
\end{array}$ & $\begin{array}{c}0.362 \\
(0.481) \\
\end{array}$ & $\begin{array}{c}0.435 \\
(0.496) \\
\end{array}$ & $\begin{array}{c}0.414 \\
(0.493) \\
\end{array}$ & $\begin{array}{c}0.271 \\
(0.445) \\
\end{array}$ & $\begin{array}{c}0.250 \\
(0.433) \\
\end{array}$ & $\begin{array}{c}0.361 \\
(0.482) \\
\end{array}$ & $\begin{array}{c}0.331 \\
(0.471) \\
\end{array}$ \\
\hline & $\begin{array}{c}0.062 \\
(0.241) \\
\end{array}$ & $\begin{array}{c}0.060 \\
(0.238) \\
\end{array}$ & $\begin{array}{c}0.188 \\
(0.390) \\
\end{array}$ & $\begin{array}{c}0.188 \\
(0.391) \\
\end{array}$ & $\begin{array}{c}0.055 \\
(0.228) \\
\end{array}$ & $\begin{array}{c}0.054 \\
(0.226) \\
\end{array}$ & $\begin{array}{c}0.174 \\
(0.379) \\
\end{array}$ & $\begin{array}{c}0.173 \\
(0.378) \\
\end{array}$ & $\begin{array}{c}0.069 \\
(0.253) \\
\end{array}$ & $\begin{array}{c}0.067 \\
(0.250) \\
\end{array}$ & $\begin{array}{c}0.289 \\
(0.453) \\
\end{array}$ & $\begin{array}{c}0.293 \\
(0.455) \\
\end{array}$ \\
\hline & $\begin{array}{c}0.349 \\
(0.477) \\
\end{array}$ & $\begin{array}{c}0.349 \\
(0.477) \\
\end{array}$ & $\begin{array}{c}0.257 \\
(0.437) \\
\end{array}$ & $\begin{array}{c}0.248 \\
(0.432) \\
\end{array}$ & $\begin{array}{c}0.268 \\
(0.443) \\
\end{array}$ & $\begin{array}{c}0.273 \\
(0.445) \\
\end{array}$ & $\begin{array}{c}0.249 \\
(0.432) \\
\end{array}$ & $\begin{array}{c}0.241 \\
(0.427) \\
\end{array}$ & $\begin{array}{c}0.437 \\
(0.496) \\
\end{array}$ & $\begin{array}{c}0.425 \\
(0.494) \\
\end{array}$ & $\begin{array}{c}0.319 \\
(0.466) \\
\end{array}$ & $\begin{array}{c}0.303 \\
(0.459) \\
\end{array}$ \\
\hline & $\begin{array}{c}0.296 \\
(0.456) \\
\end{array}$ & $\begin{array}{c}0.311 \\
(0.463) \\
\end{array}$ & $\begin{array}{c}0.255 \\
(0.436) \\
\end{array}$ & $\begin{array}{c}0.266 \\
(0.442) \\
\end{array}$ & $\begin{array}{c}0.257 \\
(0.437) \\
\end{array}$ & $\begin{array}{c}0.269 \\
(0.443) \\
\end{array}$ & $\begin{array}{c}0.254 \\
(0.435) \\
\end{array}$ & $\begin{array}{c}0.265 \\
(0.441) \\
\end{array}$ & $\begin{array}{c}0.337 \\
(0.473) \\
\end{array}$ & $\begin{array}{c}0.353 \\
(0.478) \\
\end{array}$ & $\begin{array}{c}0.265 \\
(0.441) \\
\end{array}$ & $\begin{array}{c}0.277 \\
(0.447) \\
\end{array}$ \\
\hline & $\begin{array}{c}0.293 \\
(0.455) \\
\end{array}$ & $\begin{array}{c}0.280 \\
(0.449) \\
\end{array}$ & $\begin{array}{c}0.300 \\
(0.458) \\
\end{array}$ & $\begin{array}{c}0.297 \\
(0.457) \\
\end{array}$ & $\begin{array}{c}0.420 \\
(0.493) \\
\end{array}$ & $\begin{array}{c}0.405 \\
(0.491) \\
\end{array}$ & $\begin{array}{c}0.323 \\
(0.468) \\
\end{array}$ & $\begin{array}{c}0.321 \\
(0.467) \\
\end{array}$ & $\begin{array}{c}0.157 \\
(0.364) \\
\end{array}$ & $\begin{array}{c}0.155 \\
(0.362) \\
\end{array}$ & $\begin{array}{c}0.127 \\
(0.333) \\
\end{array}$ & $\begin{array}{c}0.127 \\
(0.333) \\
\end{array}$ \\
\hline & $\begin{array}{c}0.548 \\
(0.498) \\
\end{array}$ & $\begin{array}{c}0.553 \\
(0.497) \\
\end{array}$ & $\begin{array}{c}0.514 \\
(0.500) \\
\end{array}$ & $\begin{array}{c}0.512 \\
(0.500) \\
\end{array}$ & $\begin{array}{c}0.491 \\
(0.500) \\
\end{array}$ & $\begin{array}{c}0.492 \\
(0.500) \\
\end{array}$ & $\begin{array}{c}0.510 \\
(0.500) \\
\end{array}$ & $\begin{array}{c}0.509 \\
(0.500) \\
\end{array}$ & $\begin{array}{c}0.610 \\
(0.488) \\
\end{array}$ & $\begin{array}{c}0.614 \\
(0.487) \\
\end{array}$ & $\begin{array}{c}0.544 \\
(0.498) \\
\end{array}$ & $\begin{array}{c}0.534 \\
(0.499) \\
\end{array}$ \\
\hline & $\begin{array}{c}0.347 \\
(0.476) \\
\end{array}$ & $\begin{array}{c}0.324 \\
(0.468) \\
\end{array}$ & $\begin{array}{c}0.384 \\
(0.486) \\
\end{array}$ & $\begin{array}{c}0.373 \\
(0.484) \\
\end{array}$ & $\begin{array}{c}0.401 \\
(0.490) \\
\end{array}$ & $\begin{array}{c}0.382 \\
(0.486) \\
\end{array}$ & $\begin{array}{c}0.393 \\
(0.488) \\
\end{array}$ & $\begin{array}{c}0.380 \\
(0.485) \\
\end{array}$ & $\begin{array}{c}0.289 \\
(0.453) \\
\end{array}$ & $\begin{array}{c}0.266 \\
(0.442) \\
\end{array}$ & $\begin{array}{c}0.322 \\
(0.467) \\
\end{array}$ & $\begin{array}{c}0.322 \\
(0.467) \\
\end{array}$ \\
\hline & $\begin{array}{c}0.452 \\
(0.498) \\
\end{array}$ & $\begin{array}{c}0.461 \\
(0.498) \\
\end{array}$ & $\begin{array}{c}0.385 \\
(0.487) \\
\end{array}$ & $\begin{array}{c}0.391 \\
(0.488) \\
\end{array}$ & $\begin{array}{c}0.437 \\
(0.496) \\
\end{array}$ & $\begin{array}{c}0.445 \\
(0.497) \\
\end{array}$ & $\begin{array}{c}0.387 \\
(0.487) \\
\end{array}$ & $\begin{array}{c}0.393 \\
(0.489) \\
\end{array}$ & $\begin{array}{c}0.468 \\
(0.499) \\
\end{array}$ & $\begin{array}{c}0.476 \\
(0.499) \\
\end{array}$ & $\begin{array}{c}0.367 \\
(0.482) \\
\end{array}$ & $\begin{array}{c}0.370 \\
(0.483) \\
\end{array}$ \\
\hline & $\begin{array}{c}0.201 \\
(0.401) \\
\end{array}$ & $\begin{array}{c}0.215 \\
(0.411) \\
\end{array}$ & $\begin{array}{c}0.231 \\
(0.421) \\
\end{array}$ & $\begin{array}{c}0.236 \\
(0.425) \\
\end{array}$ & $\begin{array}{c}0.162 \\
(0.369) \\
\end{array}$ & $\begin{array}{c}0.172 \\
(0.378) \\
\end{array}$ & $\begin{array}{c}0.220 \\
(0.414) \\
\end{array}$ & $\begin{array}{c}0.226 \\
(0.418) \\
\end{array}$ & $\begin{array}{c}0.243 \\
(0.429) \\
\end{array}$ & $\begin{array}{c}0.258 \\
(0.438) \\
\end{array}$ & $\begin{array}{c}0.311 \\
(0.463) \\
\end{array}$ & $\begin{array}{c}0.308 \\
(0.462) \\
\end{array}$ \\
\hline & $\begin{array}{c}0.653 \\
(0.476) \\
\end{array}$ & $\begin{array}{c}0.656 \\
(0.475) \\
\end{array}$ & $\begin{array}{c}0.790 \\
(0.408) \\
\end{array}$ & $\begin{array}{c}0.772 \\
(0.419) \\
\end{array}$ & $\begin{array}{c}0.455 \\
(0.498) \\
\end{array}$ & $\begin{array}{c}0.432 \\
(0.495) \\
\end{array}$ & $\begin{array}{c}0.773 \\
(0.419) \\
\end{array}$ & $\begin{array}{c}0.752 \\
(0.432) \\
\end{array}$ & $\begin{array}{c}0.867 \\
(0.340) \\
\end{array}$ & $\begin{array}{c}0.880 \\
(0.325) \\
\end{array}$ & $\begin{array}{c}0.915 \\
(0.279) \\
\end{array}$ & $\begin{array}{c}0.921 \\
(0.270) \\
\end{array}$ \\
\hline & $\begin{array}{c}0.067 \\
(0.250) \\
\end{array}$ & $\begin{array}{r}0.107 \\
(0.309) \\
\end{array}$ & $\begin{array}{c}0.036 \\
(0.185) \\
\end{array}$ & $\begin{array}{c}0.075 \\
(0.263) \\
\end{array}$ & $\begin{array}{c}0.112 \\
(0.316) \\
\end{array}$ & $\begin{array}{c}0.201 \\
(0.401) \\
\end{array}$ & $\begin{array}{c}0.039 \\
(0.193) \\
\end{array}$ & $\begin{array}{c}0.083 \\
(0.276) \\
\end{array}$ & $\begin{array}{c}0.018 \\
(0.131) \\
\end{array}$ & $\begin{array}{c}0.012 \\
(0.111) \\
\end{array}$ & $\begin{array}{c}0.012 \\
(0.108) \\
\end{array}$ & $\begin{array}{c}0.017 \\
(0.130) \\
\end{array}$ \\
\hline & $\begin{array}{c}0.234 \\
(0.423) \\
\end{array}$ & $\begin{array}{c}0.205 \\
(0.403) \\
\end{array}$ & $\begin{array}{c}0.155 \\
(0.362) \\
\end{array}$ & $\begin{array}{c}0.139 \\
(0.346) \\
\end{array}$ & $\begin{array}{c}0.354 \\
(0.478) \\
\end{array}$ & $\begin{array}{c}0.307 \\
(0.461) \\
\end{array}$ & $\begin{array}{c}0.168 \\
(0.374) \\
\end{array}$ & $\begin{array}{c}0.151 \\
(0.358) \\
\end{array}$ & $\begin{array}{c}0.104 \\
(0.305) \\
\end{array}$ & $\begin{array}{c}0.102 \\
(0.303) \\
\end{array}$ & $\begin{array}{c}0.059 \\
(0.235) \\
\end{array}$ & $\begin{array}{c}0.054 \\
(0.225) \\
\end{array}$ \\
\hline & $\begin{array}{c}0.010 \\
(0.098) \\
\end{array}$ & $\begin{array}{c}0.004 \\
(0.066) \\
\end{array}$ & $\begin{array}{c}0.002 \\
(0.043) \\
\end{array}$ & $\begin{array}{c}0.002 \\
(0.049) \\
\end{array}$ & $\begin{array}{c}0.012 \\
(0.110) \\
\end{array}$ & $\begin{array}{c}0.009 \\
(0.092) \\
\end{array}$ & $\begin{array}{c}0.002 \\
(0.042) \\
\end{array}$ & $\begin{array}{c}0.003 \\
(0.051) \\
\end{array}$ & $\begin{array}{c}0.007 \\
(0.084) \\
\end{array}$ & $\begin{array}{c}0.000 \\
(0.019) \\
\end{array}$ & $\begin{array}{c}0.002 \\
(0.048) \\
\end{array}$ & $\begin{array}{c}0.001 \\
(0.032) \\
\end{array}$ \\
\hline & $\begin{array}{c}0.036 \\
(0.185) \\
\end{array}$ & $\begin{array}{r}0.027 \\
(0.163) \\
\end{array}$ & $\begin{array}{c}0.017 \\
(0.131) \\
\end{array}$ & $\begin{array}{c}0.011 \\
(0.104) \\
\end{array}$ & $\begin{array}{c}0.064 \\
(0.245) \\
\end{array}$ & $\begin{array}{c}0.050 \\
(0.219) \\
\end{array}$ & $\begin{array}{c}0.018 \\
(0.133) \\
\end{array}$ & $\begin{array}{c}0.011 \\
(0.106) \\
\end{array}$ & $\begin{array}{c}0.005 \\
(0.068) \\
\end{array}$ & $\begin{array}{c}0.005 \\
(0.068) \\
\end{array}$ & $\begin{array}{c}0.012 \\
(0.109) \\
\end{array}$ & $\begin{array}{c}0.007 \\
(0.085) \\
\end{array}$ \\
\hline & $\begin{array}{c}0.001 \\
(0.035) \\
\end{array}$ & $\begin{array}{c}0.001 \\
(0.024) \\
\end{array}$ & $\begin{array}{c}0.000 \\
(0.019) \\
\end{array}$ & $\begin{array}{c}0.000 \\
(0.016) \\
\end{array}$ & $\begin{array}{c}0.002 \\
(0.048) \\
\end{array}$ & $\begin{array}{c}0.001 \\
(0.035) \\
\end{array}$ & $\begin{array}{c}0.000 \\
(0.020) \\
\end{array}$ & $\begin{array}{c}0.000 \\
(0.016) \\
\end{array}$ & $\begin{array}{c}0.000 \\
(0.000) \\
\end{array}$ & $\begin{array}{c}0.000 \\
(0.000) \\
\end{array}$ & $\begin{array}{c}0.000 \\
(0.009) \\
\end{array}$ & $\begin{array}{r}0.000 \\
(0.019) \\
\end{array}$ \\
\hline & $\begin{array}{r}9.098 \\
(0.692) \\
\end{array}$ & $\begin{array}{r}9.152 \\
(0.605) \\
\end{array}$ & $\begin{array}{r}8.169 \\
(0.519) \\
\end{array}$ & $\begin{array}{r}8.284 \\
(0.464) \\
\end{array}$ & $\begin{array}{r}9.321 \\
(0.574) \\
\end{array}$ & $\begin{array}{r}9.332 \\
(0.505) \\
\end{array}$ & $\begin{array}{c}8.181 \\
(0.517) \\
\end{array}$ & $\begin{array}{c}8.292 \\
(0.468) \\
\end{array}$ & $\begin{array}{c}8.857 \\
(0.726) \\
\end{array}$ & $\begin{array}{r}8.973 \\
(0.642) \\
\end{array}$ & $\begin{array}{c}8.081 \\
(0.527) \\
\end{array}$ & $\begin{array}{r}8.231 \\
(0.431) \\
\end{array}$ \\
\hline & $\begin{array}{c}6.379 \\
(8.761) \\
\end{array}$ & $\begin{array}{r}5.456 \\
(7.648) \\
\end{array}$ & $\begin{array}{c}5.451 \\
(6.838) \\
\end{array}$ & $\begin{array}{r}5.015 \\
(6.256) \\
\end{array}$ & $\begin{array}{r}8.571 \\
(10.51) \\
\end{array}$ & $\begin{array}{c}7.168 \\
(9.406) \\
\end{array}$ & $\begin{array}{r}5.272 \\
(6.420) \\
\end{array}$ & $\begin{array}{c}4.812 \\
(5.751) \\
\end{array}$ & $\begin{array}{c}4.011 \\
(5.429) \\
\end{array}$ & $\begin{array}{r}3.748 \\
(4.768) \\
\end{array}$ & $\begin{array}{c}6.786 \\
(9.279) \\
\end{array}$ & $\begin{array}{r}6.476 \\
(8.970) \\
\end{array}$ \\
\hline & $\begin{array}{c}0.342 \\
(0,474) \\
\end{array}$ & $\begin{array}{r}0.331 \\
(0.471) \\
\end{array}$ & $\begin{array}{c}0.349 \\
(0.477) \\
\end{array}$ & $\begin{array}{c}0.352 \\
(0.478) \\
\end{array}$ & $\begin{array}{c}0.407 \\
(0,491) \\
\end{array}$ & $\begin{array}{c}0.392 \\
(0.488) \\
\end{array}$ & $\begin{array}{c}0.354 \\
(0.478) \\
\end{array}$ & $\begin{array}{c}0.355 \\
(0.479) \\
\end{array}$ & $\begin{array}{c}0.272 \\
(0,445) \\
\end{array}$ & $\begin{array}{c}0.271 \\
(0.444) \\
\end{array}$ & $\begin{array}{c}0.318 \\
(0.466) \\
\end{array}$ & $\begin{array}{c}0.333 \\
(0.471) \\
\end{array}$ \\
\hline GP & $\begin{array}{c}0.084 \\
(0.016) \\
\end{array}$ & $\begin{array}{c}0.086 \\
(0.016) \\
\end{array}$ & $\begin{array}{r}0.084 \\
(0.017) \\
\end{array}$ & $\begin{array}{c}0.086 \\
(0.016) \\
\end{array}$ & $\begin{array}{c}0.084 \\
(0.016) \\
\end{array}$ & $\begin{array}{c}0.086 \\
(0.016) \\
\end{array}$ & $\begin{array}{c}0.084 \\
(0.016) \\
\end{array}$ & $\begin{array}{r}0.086 \\
0.016) \\
\end{array}$ & $\begin{array}{c}0.084 \\
(0.016) \\
\end{array}$ & $\begin{array}{c}0.086 \\
(0.016) \\
\end{array}$ & $\begin{array}{c}0.085 \\
(0.018) \\
\end{array}$ & $\begin{array}{c}0.087 \\
(0.017) \\
\end{array}$ \\
\hline 1 & $\begin{array}{c}41.08 \\
(23.07) \\
\end{array}$ & $\begin{array}{r}39.18 \\
(22.64) \\
\end{array}$ & $\begin{array}{c}40.93 \\
(23.09) \\
\end{array}$ & $\begin{array}{c}38.70 \\
(22.20) \\
\end{array}$ & $\begin{array}{c}40.89 \\
(23.06) \\
\end{array}$ & $\begin{array}{c}39.08 \\
(22.70) \\
\end{array}$ & $\begin{array}{c}40.80 \\
(22.96) \\
\end{array}$ & $\begin{array}{c}38.55 \\
(22.06) \\
\end{array}$ & $\begin{array}{c}41.28 \\
(23.08) \\
\end{array}$ & $\begin{array}{r}39.29 \\
(22.59) \\
\end{array}$ & $\begin{array}{c}41.88 \\
(24.01) \\
\end{array}$ & $\begin{array}{r}39.75 \\
(23.17) \\
\end{array}$ \\
\hline st & $\begin{array}{c}0.396 \\
(0.159) \\
\end{array}$ & $\begin{array}{r}0.469 \\
(0.186) \\
\end{array}$ & $\begin{array}{r}0.394 \\
(0.158) \\
\end{array}$ & $\begin{array}{c}0.467 \\
(0.180) \\
\end{array}$ & $\begin{array}{r}0.396 \\
(0.159) \\
\end{array}$ & $\begin{array}{c}0.467 \\
(0.186) \\
\end{array}$ & $\begin{array}{r}0.394 \\
(0.157) \\
\end{array}$ & $\begin{array}{c}0.466 \\
(0.178) \\
\end{array}$ & $\begin{array}{c}0.397 \\
(0.159) \\
\end{array}$ & $\begin{array}{c}0.471 \\
(0.186) \\
\end{array}$ & $\begin{array}{c}0.389 \\
(0.161) \\
\end{array}$ & $\begin{array}{c}0.469 \\
(0.189) \\
\end{array}$ \\
\hline i80 & $\begin{array}{c}18.45 \\
(4.343) \\
\end{array}$ & $\begin{array}{r}18.67 \\
(4.385) \\
\end{array}$ & $\begin{array}{r}18.45 \\
(4.311) \\
\end{array}$ & $\begin{array}{r}18.70 \\
(4.393) \\
\end{array}$ & $\begin{array}{r}18.54 \\
(4.347) \\
\end{array}$ & $\begin{array}{c}18.73 \\
(4.380) \\
\end{array}$ & $\begin{array}{c}18.47 \\
(4.280) \\
\end{array}$ & $\begin{array}{c}18.71 \\
(4.373) \\
\end{array}$ & $\begin{array}{r}18.35 \\
(4.335) \\
\end{array}$ & $\begin{array}{c}18.61 \\
(4.390) \\
\end{array}$ & $\begin{array}{r}18.34 \\
(4.533) \\
\end{array}$ & $\begin{array}{c}18.59 \\
(4.533) \\
\end{array}$ \\
\hline & $\begin{array}{r}13.99 \\
(3.299) \\
\end{array}$ & $\begin{array}{r}13.93 \\
(3.385) \\
\end{array}$ & $\begin{array}{c}14.03 \\
(3.340) \\
\end{array}$ & $\begin{array}{c}13.97 \\
(3.366) \\
\end{array}$ & $\begin{array}{r}14.09 \\
(3.322) \\
\end{array}$ & $\begin{array}{c}14.03 \\
(3.416) \\
\end{array}$ & $\begin{array}{c}14.04 \\
(3.328) \\
\end{array}$ & $\begin{array}{c}13.99 \\
(3.366) \\
\end{array}$ & $\begin{array}{r}13.87 \\
(3.270) \\
\end{array}$ & $\begin{array}{r}13.84 \\
(3.350) \\
\end{array}$ & $\begin{array}{c}13.92 \\
(3.432) \\
\end{array}$ & $\begin{array}{r}13.79 \\
(3.362) \\
\end{array}$ \\
\hline
\end{tabular}


Table 3: Descriptive statistics on patient distributions pre- and post-reform period by alternative pathways

\begin{tabular}{|c|c|c|c|c|c|c|}
\hline \multirow[t]{3}{*}{ ariable } & \multicolumn{2}{|c|}{$\begin{array}{c}\mathbf{H}_{\mathbf{o}}-\mathrm{H}-\mathrm{H}_{\mathbf{o}} \\
(\mathrm{N}=411,621)\end{array}$} & \multicolumn{2}{|c|}{$\begin{array}{c}\mathrm{H}_{\mathrm{o}}-\mathrm{H}-\mathrm{S}_{\mathrm{c}} \\
(\mathrm{N}=34,170)\end{array}$} & \multicolumn{2}{|c|}{$\begin{array}{c}\mathrm{H}_{\mathrm{o}}-\mathrm{H}-\mathrm{O}_{\mathrm{h}} \\
(\mathrm{N}=89,421)\end{array}$} \\
\hline & $\begin{array}{l}\text { Pre-reform } \\
(\mathrm{N}=206,33) \\
\end{array}$ & $\begin{array}{c}\text { Post-reform } \\
(\mathrm{N}=205,288)\end{array}$ & $\begin{array}{c}\text { Pre-reform } \\
(\mathrm{N}=11,567) \\
\end{array}$ & $\begin{array}{l}\text { Post-reform } \\
(\mathrm{N}=22,603)\end{array}$ & $\begin{array}{l}\text { Pre-reform } \\
(\mathrm{N}=46,964) \\
\end{array}$ & $\begin{array}{l}\text { Post-reform } \\
(\mathrm{N}=42,457)\end{array}$ \\
\hline & $\begin{array}{c}\text { Mean } \\
\text { (Std. Dev) }\end{array}$ & $\begin{array}{c}\text { Mean } \\
\text { (Std. Dev) }\end{array}$ & $\begin{array}{c}\text { Mean } \\
\text { (Std. Dev) } \\
\end{array}$ & $\begin{array}{c}\text { Mean } \\
\text { (Std. Dev) } \\
\end{array}$ & $\begin{array}{c}\text { Mean } \\
\text { (Std. Dev) } \\
\end{array}$ & $\begin{array}{c}\text { Mean } \\
\text { (Std. Dev) } \\
\end{array}$ \\
\hline irv_30 & $\begin{array}{c}0.985 \\
(0.123) \\
\end{array}$ & $\begin{array}{c}0.984 \\
(0.127) \\
\end{array}$ & $\begin{array}{c}0.895 \\
(0.306) \\
\end{array}$ & $\begin{array}{c}0.898 \\
(0.301)\end{array}$ & $\begin{array}{c}0.804 \\
(0.397) \\
\end{array}$ & $\begin{array}{c}0.815 \\
(0.389) \\
\end{array}$ \\
\hline$\overline{\text { urv_90 }}$ & $\begin{array}{c}0.954 \\
(0.209) \\
\end{array}$ & $\begin{array}{c}0.959 \\
(0.199) \\
\end{array}$ & $\begin{array}{c}0.776 \\
(0.417) \\
\end{array}$ & $\begin{array}{c}0.794 \\
(0.404) \\
\end{array}$ & $\begin{array}{c}0.738 \\
(0.440) \\
\end{array}$ & $\begin{array}{c}0.765 \\
(0.424) \\
\end{array}$ \\
\hline$\overline{\text { ulti }}$ & $\begin{array}{c}0.365 \\
(0.488) \\
\end{array}$ & $\begin{array}{c}0.340 \\
(0.473) \\
\end{array}$ & $\begin{array}{c}0.519 \\
(0.500) \\
\end{array}$ & $\begin{array}{c}0.518 \\
(0.500) \\
\end{array}$ & $\begin{array}{c}0.528 \\
(0.499) \\
\end{array}$ & $\begin{array}{c}0.494 \\
(0.500) \\
\end{array}$ \\
\hline$\overline{y e 44}$ & $\begin{array}{c}0.198 \\
(0.399)\end{array}$ & $\begin{array}{c}0.200 \\
(0.400)\end{array}$ & $\begin{array}{c}0.011 \\
(0.103)\end{array}$ & $\begin{array}{c}0.006 \\
(0.074)\end{array}$ & $\begin{array}{c}0.042 \\
(0.201)\end{array}$ & $\begin{array}{c}0.052 \\
(0.222)\end{array}$ \\
\hline ye66 & $\begin{array}{c}0.299 \\
(0.458) \\
\end{array}$ & $\begin{array}{c}0.298 \\
(0.457) \\
\end{array}$ & $\begin{array}{c}0.085 \\
(0.278) \\
\end{array}$ & $\begin{array}{c}0.070 \\
(0.255) \\
\end{array}$ & $\begin{array}{c}0.235 \\
(0.424) \\
\end{array}$ & $\begin{array}{c}0.254 \\
(0.435) \\
\end{array}$ \\
\hline ye79 & $\begin{array}{c}0.266 \\
(0.442) \\
\end{array}$ & $\begin{array}{c}0.280 \\
(0.449) \\
\end{array}$ & $\begin{array}{c}0.217 \\
(0.412) \\
\end{array}$ & $\begin{array}{c}0.226 \\
(0.418) \\
\end{array}$ & $\begin{array}{c}0.267 \\
(0.442) \\
\end{array}$ & $\begin{array}{c}0.287 \\
(0.453) \\
\end{array}$ \\
\hline ye80 & $\begin{array}{c}0.237 \\
(0.426) \\
\end{array}$ & $\begin{array}{c}0.222 \\
(0.416) \\
\end{array}$ & $\begin{array}{c}0.687 \\
(0.464) \\
\end{array}$ & $\begin{array}{c}0.699 \\
(0.459) \\
\end{array}$ & $\begin{array}{c}0.456 \\
(0.498) \\
\end{array}$ & $\begin{array}{c}0.406 \\
(0.491) \\
\end{array}$ \\
\hline ale & $\begin{array}{c}0.530 \\
(0.499) \\
\end{array}$ & $\begin{array}{c}0.533 \\
(0.499) \\
\end{array}$ & $\begin{array}{c}0.393 \\
(0.489) \\
\end{array}$ & $\begin{array}{c}0.390 \\
(0.488) \\
\end{array}$ & $\begin{array}{c}0.517 \\
(0.500) \\
\end{array}$ & $\begin{array}{c}0.534 \\
(0.499) \\
\end{array}$ \\
\hline lu1 & $\begin{array}{c}0.358 \\
(0.479) \\
\end{array}$ & $\begin{array}{c}0.342 \\
(0.474) \\
\end{array}$ & $\begin{array}{c}0.499 \\
(0.500) \\
\end{array}$ & $\begin{array}{c}0.464 \\
(0.499) \\
\end{array}$ & $\begin{array}{c}0.418 \\
(0.493) \\
\end{array}$ & $\begin{array}{c}0.402 \\
(0.490) \\
\end{array}$ \\
\hline du2 & $\begin{array}{c}0.392 \\
(0.488) \\
\end{array}$ & $\begin{array}{c}0.399 \\
(0.490) \\
\end{array}$ & $\begin{array}{c}0.387 \\
(0.487) \\
\end{array}$ & $\begin{array}{c}0.420 \\
(0.494) \\
\end{array}$ & $\begin{array}{c}0.429 \\
(0.495) \\
\end{array}$ & $\begin{array}{c}0.432 \\
(0.495) \\
\end{array}$ \\
\hline lu3 & $\begin{array}{c}0.250 \\
(0.433) \\
\end{array}$ & $\begin{array}{c}0.259 \\
(0.438) \\
\end{array}$ & $\begin{array}{c}0.114 \\
(0.318) \\
\end{array}$ & $\begin{array}{c}0.116 \\
(0.321) \\
\end{array}$ & $\begin{array}{c}0.152 \\
(0.359) \\
\end{array}$ & $\begin{array}{c}0.166 \\
(0.372) \\
\end{array}$ \\
\hline g_log & $\begin{array}{c}8.269 \\
(0.632) \\
\end{array}$ & $\begin{array}{c}8.389 \\
(0.577) \\
\end{array}$ & $\begin{array}{c}8.796 \\
(0.633) \\
\end{array}$ & $\begin{array}{c}8.778 \\
(0.559) \\
\end{array}$ & $\begin{array}{c}8.697 \\
(0.737) \\
\end{array}$ & $\begin{array}{c}8.756 \\
(0.698) \\
\end{array}$ \\
\hline$\overline{\mathrm{JS}}$ & $\begin{array}{c}4.856 \\
(6.277) \\
\end{array}$ & $\begin{array}{c}4.538 \\
(5.969) \\
\end{array}$ & $\begin{array}{c}9.295 \\
(9.676) \\
\end{array}$ & $\begin{array}{c}7.509 \\
(7.713) \\
\end{array}$ & $\begin{array}{c}8.106 \\
(9.349) \\
\end{array}$ & $\begin{array}{c}6.550 \\
(7.907) \\
\end{array}$ \\
\hline$\overline{\text { JS_M }}$ & $\begin{array}{c}0.323 \\
(0.468) \\
\end{array}$ & $\begin{array}{c}0.328 \\
(0.469) \\
\end{array}$ & $\begin{array}{c}0.471 \\
(0.499) \\
\end{array}$ & $\begin{array}{c}0.456 \\
(0.498) \\
\end{array}$ & $\begin{array}{c}0.428 \\
(0.495) \\
\end{array}$ & $\begin{array}{c}0.387 \\
(0.487) \\
\end{array}$ \\
\hline эrcap_GP & $\begin{array}{c}0.084 \\
(0.016) \\
\end{array}$ & $\begin{array}{c}0.086 \\
(0.016) \\
\end{array}$ & $\begin{array}{c}0.084 \\
(0.017) \\
\end{array}$ & $\begin{array}{c}0.084 \\
(0.016) \\
\end{array}$ & $\begin{array}{c}0.084 \\
(0.016) \\
\end{array}$ & $\begin{array}{c}0.086 \\
(0.015) \\
\end{array}$ \\
\hline P_open & $\begin{array}{r}40.66 \\
(23.01) \\
\end{array}$ & $\begin{array}{r}38.63 \\
(22.38) \\
\end{array}$ & $\begin{array}{r}44.03 \\
(23.27) \\
\end{array}$ & $\begin{array}{r}39.70 \\
(20.98) \\
\end{array}$ & $\begin{array}{r}41.97 \\
(23.07) \\
\end{array}$ & $\begin{array}{r}39.14 \\
(22.66) \\
\end{array}$ \\
\hline ays_Inst & $\begin{array}{c}0.396 \\
(0.160) \\
\end{array}$ & $\begin{array}{c}0.468 \\
(0.184) \\
\end{array}$ & $\begin{array}{c}0.409 \\
(0.162) \\
\end{array}$ & $\begin{array}{r}0.485 \\
(0.181) \\
\end{array}$ & $\begin{array}{c}0.388 \\
(0.148) \\
\end{array}$ & $\begin{array}{c}0.457 \\
(0.172) \\
\end{array}$ \\
\hline st_resi80 & $\begin{array}{c}18.45 \\
(4.312) \\
\end{array}$ & $\begin{array}{c}18.70 \\
(4.389) \\
\end{array}$ & $\begin{array}{c}18.42 \\
(4.459) \\
\end{array}$ & $\begin{array}{c}18.92 \\
(4.274) \\
\end{array}$ & $\begin{array}{c}18.50 \\
(4.252) \\
\end{array}$ & $\begin{array}{c}18.56 \\
(4.428) \\
\end{array}$ \\
\hline st_80 & $\begin{array}{c}14.00 \\
(3.322) \\
\end{array}$ & $\begin{array}{c}13.96 \\
(3.373) \\
\end{array}$ & $\begin{array}{c}13.81 \\
(3.297) \\
\end{array}$ & $\begin{array}{c}13.96 \\
(3.183) \\
\end{array}$ & $\begin{array}{c}14.13 \\
(3.325) \\
\end{array}$ & $\begin{array}{c}13.96 \\
(3.427) \\
\end{array}$ \\
\hline v_alone & $\begin{array}{r}39.08 \\
(9.106) \\
\end{array}$ & $\begin{array}{r}38.50 \\
(8.816) \\
\end{array}$ & $\begin{array}{r}38.09 \\
(9.137) \\
\end{array}$ & $\begin{array}{r}37.80 \\
(8.496) \\
\end{array}$ & $\begin{array}{r}39.61 \\
(9.388) \\
\end{array}$ & $\begin{array}{r}38.88 \\
(9.145) \\
\end{array}$ \\
\hline
\end{tabular}


Table 4: Main DiD results for all patients with chronic conditions and for alternative in-patient admissions

\begin{tabular}{|c|c|c|c|c|c|c|}
\hline \multirow[t]{2}{*}{ Variable } & \multicolumn{2}{|c|}{ All admissions } & \multicolumn{2}{|c|}{ Emergency admissions } & \multicolumn{2}{|c|}{$\begin{array}{c}\text { Planned/elective } \\
\text { admissions }\end{array}$} \\
\hline & $\begin{array}{l}\text { 30-day } \\
\text { survival }\end{array}$ & $\begin{array}{c}\text { 90-day } \\
\text { survival }\end{array}$ & $\begin{array}{l}\text { 30-day } \\
\text { survival }\end{array}$ & $\begin{array}{l}\text { 90-day } \\
\text { survival }\end{array}$ & $\begin{array}{l}\text { 30-day } \\
\text { survival }\end{array}$ & 90-day survival \\
\hline reform & $\begin{array}{l}0.0058^{* *} \\
(0.0023)\end{array}$ & $\begin{array}{l}0.0205^{* * *} \\
(0.0020)\end{array}$ & $\begin{array}{c}0.0048 \\
(0.0039)\end{array}$ & $\begin{array}{c}0.0249^{* * *} \\
(0.0036)\end{array}$ & $\begin{array}{l}0.0027^{* *} \\
(0.0011)\end{array}$ & $\begin{array}{l}0.0087^{* *} \\
(0.0023)\end{array}$ \\
\hline treat & $\begin{array}{c}- \\
0.0765^{* * *} \\
(0.0017)\end{array}$ & $\begin{array}{c}-0.1302^{\text {*** }} \\
(0.0028)\end{array}$ & $\begin{array}{c}-{ }^{*}{ }^{* * *} \\
0.1116^{* *} \\
(0.0037)\end{array}$ & $\begin{array}{c}-0.1698^{\text {*** }} \\
(0.0046)\end{array}$ & $\begin{array}{c}-0.0323^{* * *} \\
(0.0017)\end{array}$ & $\begin{array}{c}-0.0860^{* * *} \\
(0.0034)\end{array}$ \\
\hline reform*treat & $\begin{array}{l}0.0036^{* *} \\
(0.0016)\end{array}$ & $\begin{array}{c}0.0058^{* * *} \\
(0.0017) \\
\end{array}$ & $\begin{array}{l}0.0068^{* *} \\
(0.0028)\end{array}$ & $\begin{array}{c}0.0050^{*} \\
(0.0030)\end{array}$ & $\begin{array}{c}0.0003 \\
(0.0014) \\
\end{array}$ & $\begin{array}{l}0.0062^{* * *} \\
(0.0023)\end{array}$ \\
\hline$\overline{\text { multi }}$ & $\begin{array}{c}-0.0231^{* * *} \\
(0.0011) \\
\end{array}$ & $\begin{array}{l}-0.0440^{* * *} \\
(0.0014)\end{array}$ & $\begin{array}{c}-0.0212^{* * *} \\
(0.0012) \\
\end{array}$ & $\begin{array}{l}-0.0404^{* * *} \\
(0.0015)\end{array}$ & $\begin{array}{c}-0.0175^{* * *} \\
(0.0012) \\
\end{array}$ & $\begin{array}{c}-0.0422^{* * *} \\
(0.0018)\end{array}$ \\
\hline$\overline{\text { age66 }}$ & $\begin{array}{c}-0.0039^{* * *} \\
(0.0008)\end{array}$ & $\begin{array}{l}-0.0163^{* * *} \\
(0.0011) \\
\end{array}$ & $\begin{array}{c}0.0009 \\
(0.0010) \\
\end{array}$ & $\begin{array}{l}-0.0099^{* * *} \\
(0.0012)\end{array}$ & $\begin{array}{c}-0.0101^{* * *} \\
(0.0009) \\
\end{array}$ & $\begin{array}{l}-0.0280^{* * *} \\
(0.0016)\end{array}$ \\
\hline age79 & $\begin{array}{c}-0.0120^{* * *} \\
(0.0008) \\
\end{array}$ & $\begin{array}{l}-0.0343^{* * *} \\
(0.0013) \\
\end{array}$ & $\begin{array}{c}-0.0098^{* * *} \\
(0.0010) \\
\end{array}$ & $\begin{array}{c}-0.0318^{* * *} \\
(0.0016)\end{array}$ & $\begin{array}{c}-0.0120^{* * *} \\
(0.0010) \\
\end{array}$ & $\begin{array}{c}-0.0366^{* * *} \\
(0.0020) \\
\end{array}$ \\
\hline age80 & $\begin{array}{c}-0.0480^{* * *} \\
(0.0019) \\
\end{array}$ & $\begin{array}{l}-0.0867^{* * *} \\
(0.0023) \\
\end{array}$ & $\begin{array}{c}-0.0482^{* * *} \\
(0.0021) \\
\end{array}$ & $\begin{array}{c}-0.0870^{* * *} \\
(0.0026) \\
\end{array}$ & $\begin{array}{c}-0.0224^{* * *} \\
(0.0016) \\
\end{array}$ & $\begin{array}{c}-0.0611^{* * *} \\
(0.0027) \\
\end{array}$ \\
\hline$\overline{\text { male }}$ & $\begin{array}{c}-0.0061^{* * *} \\
(0.0007)\end{array}$ & $\begin{array}{l}-0.0125^{* * *} \\
(0.0008)\end{array}$ & $\begin{array}{c}-0.0077^{* * *} \\
(0.0008) \\
\end{array}$ & $\begin{array}{c}-0.0149^{* * *} \\
(0.0010)\end{array}$ & $\begin{array}{c}-0.0025^{* * *} \\
(0.0007) \\
\end{array}$ & $\begin{array}{l}-0.0067^{* * *} \\
(0.0012)\end{array}$ \\
\hline adu1 & $\begin{array}{l}-0.0008 \\
(0.0007) \\
\end{array}$ & $\begin{array}{l}-0.0039^{* * *} \\
(0.0010) \\
\end{array}$ & $\begin{array}{l}-0.0017^{*} \\
(0.0009) \\
\end{array}$ & $\begin{array}{c}-0.0051^{* * *} \\
(0.0013) \\
\end{array}$ & $\begin{array}{c}0.0004 \\
(0.0010) \\
\end{array}$ & $\begin{array}{l}-0.0030^{*} \\
(0.0016) \\
\end{array}$ \\
\hline sdu2 & $\begin{array}{l}0.0015^{* *} \\
(0.0007) \\
\end{array}$ & $\begin{array}{c}0.0011 \\
(0.0010) \\
\end{array}$ & $\begin{array}{l}0.0014^{*} \\
(0.0007) \\
\end{array}$ & $\begin{array}{c}0.0012 \\
(0.0012) \\
\end{array}$ & $\begin{array}{c}0.0005 \\
(0.0011) \\
\end{array}$ & $\begin{array}{l}-0.0014 \\
(0.0015) \\
\end{array}$ \\
\hline$\overline{\mathrm{H}_{\mathrm{O}}-\mathrm{H}-\mathrm{S}_{\mathrm{C}}}$ & $\begin{array}{c}-0.0560^{* * *} \\
(0.0036)\end{array}$ & $\begin{array}{c}-0.1122^{* * *} \\
(0.0046)\end{array}$ & $\begin{array}{c}-0.0596^{* * *} \\
(0.0042) \\
\end{array}$ & $\begin{array}{c}-0.1175^{* * *} \\
(0.0053)\end{array}$ & $\begin{array}{c}-0.0556^{* * *} \\
(0.0069) \\
\end{array}$ & $\begin{array}{c}-0.1012^{* * *} \\
(0.0090) \\
\end{array}$ \\
\hline$\overline{\mathrm{H}_{\mathrm{o}}-\mathrm{H}-\mathrm{O}_{\mathrm{h}}}$ & $\begin{array}{c}-0.1583^{* * *} \\
(0.0035) \\
\end{array}$ & $\begin{array}{c}-0.1689^{* * *} \\
(0.0039) \\
\end{array}$ & $\begin{array}{c}-0.1732^{* * *} \\
(0.0041) \\
\end{array}$ & $\begin{array}{c}-0.1851^{* * *} \\
(0.0039) \\
\end{array}$ & $\begin{array}{c}-0.0710^{* * *} \\
(0.0039) \\
\end{array}$ & $\begin{array}{c}-0.0813^{* * *} \\
(0.0048) \\
\end{array}$ \\
\hline$\overline{\mathrm{S}_{\mathrm{C}}-\mathrm{H}-\mathrm{S}_{\mathrm{C}}}$ & $\begin{array}{c}-0.0489^{* * *} \\
(0.0079)\end{array}$ & $\begin{array}{c}-0.0930^{* * *} \\
(0.0099) \\
\end{array}$ & $\begin{array}{c}-0.0579^{* * *} \\
(0.0096)\end{array}$ & $\begin{array}{c}-0.1042^{* * *} \\
(0.0107) \\
\end{array}$ & $\begin{array}{c}-0.0319^{* * *} \\
(0.0096) \\
\end{array}$ & $\begin{array}{c}-0.0659^{* * *} \\
(0.0207) \\
\end{array}$ \\
\hline$\overline{\mathrm{O}_{\mathrm{h}}-\mathrm{H}-\mathrm{O}_{\mathrm{h}}}$ & $\begin{array}{c}-0.1062^{* * *} \\
(0.0064)\end{array}$ & $\begin{array}{c}-0.1297^{* * *} \\
(0.0080)\end{array}$ & $\begin{array}{c}-0.1120^{* * *} \\
(0.0072)\end{array}$ & $\begin{array}{c}-0.1340^{* * *} \\
(0.0085)\end{array}$ & $\begin{array}{c}-0.1404^{* * *} \\
0 .(0163) \\
\end{array}$ & $\begin{array}{c}-0.1947^{* * *} \\
(0.0225)\end{array}$ \\
\hline$\overline{\mathrm{S}_{\mathrm{C}}-\mathrm{H}-\mathrm{O}_{\mathrm{h}}}$ & $\begin{array}{c}-0.2157^{* * *} \\
(0.0284)\end{array}$ & $\begin{array}{c}-0.2211^{* * *} \\
(0.0326)\end{array}$ & $\begin{array}{c}-0.2209^{* * * *} \\
(0.0264)\end{array}$ & $\begin{array}{c}-0.2232^{* * *} \\
(0.0317)\end{array}$ & $\begin{array}{c}-0.3285^{* *} \\
(0.1262) \\
\end{array}$ & $\begin{array}{c}-0.4418^{* * *} \\
(0.1197) \\
\end{array}$ \\
\hline$\overline{\text { hrg_log }}$ & $\begin{array}{c}-0.0366^{* * *} \\
(0.0009)\end{array}$ & $\begin{array}{c}-0.0691^{* * *} \\
(0.0017)\end{array}$ & $\begin{array}{c}-0.0526^{* * *} \\
(0.0015) \\
\end{array}$ & $\begin{array}{c}-0.0900^{* * *} \\
(0.0024)\end{array}$ & $\begin{array}{c}-0.0090^{* * *} \\
(0.0007) \\
\end{array}$ & $\begin{array}{c}-0.0293^{* * *} \\
(0.0015)\end{array}$ \\
\hline$\overline{\text { LOS_M }}$ & $\begin{array}{l}0.0091^{* * *} \\
(0.0009)\end{array}$ & $\begin{array}{c}-0.0048^{* * *} \\
(0.0010) \\
\end{array}$ & $\begin{array}{l}0.0124^{* * *} \\
(0.0010)\end{array}$ & $\begin{array}{c}-0.0029^{* * *} \\
(0.0011) \\
\end{array}$ & $\begin{array}{c}-0.0039^{* * *} \\
(0.0008) \\
\end{array}$ & $\begin{array}{c}-0.0111^{* * *} \\
(0.0015)\end{array}$ \\
\hline Percap_GP & $\begin{array}{l}-0.0786 \\
(0.0715) \\
\end{array}$ & $\begin{array}{l}-0.1055 \\
(0.0848) \\
\end{array}$ & $\begin{array}{l}-0.0912 \\
(0.0906) \\
\end{array}$ & $\begin{array}{l}-0.1370 \\
(0.1018) \\
\end{array}$ & $\begin{array}{c}0.0269 \\
(0.0882) \\
\end{array}$ & $\begin{array}{c}0.0921 \\
(0.1269) \\
\end{array}$ \\
\hline$\overline{\mathrm{GP}}$ _open & $\begin{array}{l}-0.0000 \\
(0.0000) \\
\end{array}$ & $\begin{array}{l}-0.0000 \\
(0.0000) \\
\end{array}$ & $\begin{array}{c}0.0000 \\
(0.0000) \\
\end{array}$ & $\begin{array}{c}0.0000 \\
(0.0000) \\
\end{array}$ & $\begin{array}{c}0.0000 \\
(0.0000) \\
\end{array}$ & $\begin{array}{c}0.0001 \\
(0.0001) \\
\end{array}$ \\
\hline Phys_Inst & $\begin{array}{l}-0.0006 \\
(0.0042) \\
\end{array}$ & $\begin{array}{l}-0.0005 \\
(0.0047) \\
\end{array}$ & $\begin{array}{l}-0.0002 \\
(0.0053) \\
\end{array}$ & $\begin{array}{l}-0.0021 \\
(0.0056) \\
\end{array}$ & $\begin{array}{l}-0.0012 \\
(0.0037) \\
\end{array}$ & $\begin{array}{c}0.0017 \\
(0.0065) \\
\end{array}$ \\
\hline [nst_resi80 & $\begin{array}{l}-0.0001 \\
(0.0004)\end{array}$ & $\begin{array}{c}0.0004 \\
(0.0005) \\
\end{array}$ & $\begin{array}{l}-0.0003 \\
(0.0005) \\
\end{array}$ & $\begin{array}{c}0.0003 \\
(0.0006) \\
\end{array}$ & $\begin{array}{c}0.0006^{*} \\
(0.0003) \\
\end{array}$ & $\begin{array}{l}-0.0009^{*} \\
(0.0005) \\
\end{array}$ \\
\hline [nst_80 & $\begin{array}{c}0.0004 \\
(0.0004) \\
\end{array}$ & $\begin{array}{l}-0.0001 \\
(0.0005) \\
\end{array}$ & $\begin{array}{c}0.0005 \\
(0.0005) \\
\end{array}$ & $\begin{array}{l}-0.0001 \\
(0.0006) \\
\end{array}$ & $\begin{array}{l}-0.0001 \\
(0.0004) \\
\end{array}$ & $\begin{array}{c}0.0004^{*} \\
(0.0006)\end{array}$ \\
\hline Liv_alone & $\begin{array}{c}0.0002 \\
(0.0001) \\
\end{array}$ & $\begin{array}{c}0.0001 \\
(0.0002) \\
\end{array}$ & $\begin{array}{c}0.0002 \\
(0.0002) \\
\end{array}$ & $\begin{array}{r}0.0000 \\
(0.0002) \\
\end{array}$ & $\begin{array}{l}0.0004^{* *} \\
(0.0002) \\
\end{array}$ & $\begin{array}{l}0.0005^{* *} \\
(0.0002\end{array}$ \\
\hline
\end{tabular}

Year fixed effects Yes Yes Yes Municipality fixed effects Yes Yes Yes 
Cluster standard errors at municipality level are in parentheses.

'*', ‘**' and '***' represent significance at the $10 \%, 5 \%$ and $1 \%$ levels, respectively.

Table 5: Results by alternative pathways and by admission type (DiD estimates)

\begin{tabular}{|c|c|c|c|c|c|c|}
\hline \multirow[t]{2}{*}{ Pathway } & \multicolumn{2}{|c|}{ All admissions } & \multicolumn{2}{|c|}{ Emergency } & \multicolumn{2}{|c|}{ Planned } \\
\hline & $\begin{array}{c}30- \\
\text { day } \\
\text { survival }\end{array}$ & $\begin{array}{c}\text { 90-day } \\
\text { survival }\end{array}$ & $\begin{array}{l}\text { 30-day } \\
\text { survival }\end{array}$ & $\begin{array}{c}\text { 90-day } \\
\text { survival }\end{array}$ & $\begin{array}{l}\text { 30-day } \\
\text { survival }\end{array}$ & $\begin{array}{c}\text { 90-day } \\
\text { survival }\end{array}$ \\
\hline \multirow{2}{*}{$\begin{array}{l}\text { Pathway: } \mathrm{H}_{\mathrm{o}}-\mathrm{H}- \\
\mathrm{H}_{\mathrm{o}}\end{array}$} & $\begin{array}{l}-0.0007 \\
(0.0009) \\
\end{array}$ & $\begin{array}{c}0.0020 \\
(0.0013) \\
\end{array}$ & $\begin{array}{c}0.0015 \\
(0.0017) \\
\end{array}$ & $\begin{array}{c}0.0032 \\
(0.0027) \\
\end{array}$ & $\begin{array}{l}-0.0007 \\
(0.0010) \\
\end{array}$ & $\begin{array}{c}0.0031 \\
(0.0019) \\
\end{array}$ \\
\hline & \multicolumn{2}{|c|}{$[\mathrm{N}=411,621]$} & \multicolumn{2}{|c|}{$[\mathrm{N}=311,838]$} & \multicolumn{2}{|c|}{$[\mathrm{N}=99,783]$} \\
\hline \multirow[t]{2}{*}{$\begin{array}{l}\text { Pathway: } \mathrm{H}_{0}-\mathrm{H}- \\
\mathrm{S}_{\mathrm{c}}\end{array}$} & $\begin{array}{l}0.0153^{* *} \\
(0.0071)\end{array}$ & $\begin{array}{l}0.0204^{* *} \\
(0.0089)\end{array}$ & $\begin{array}{l}0.0150^{* *} \\
(0.0072)\end{array}$ & $\begin{array}{c}0.0173^{*} \\
(0.0090)\end{array}$ & $\begin{array}{c}- \\
0.0748^{* * *} \\
(0.0249)\end{array}$ & $\begin{array}{c}-0.1362^{* * *} \\
(0.0411)\end{array}$ \\
\hline & \multicolumn{2}{|c|}{$[N=34,170]$} & \multicolumn{2}{|c|}{$[N=32,525]$} & \multicolumn{2}{|c|}{$[\mathrm{N}=1,645]$} \\
\hline \multirow[t]{2}{*}{$\begin{array}{l}\text { Pathway: } \mathrm{H}_{\mathrm{o}}-\mathrm{H}- \\
\mathrm{O}_{\mathrm{h}}\end{array}$} & $\begin{array}{l}0.0141^{* *} \\
(0.0067) \\
\end{array}$ & $\begin{array}{l}0.0238^{* * * *} \\
(0.0068)\end{array}$ & $\begin{array}{l}0.0176^{* * * *} \\
(0.0066)\end{array}$ & $\begin{array}{l}0.0256^{* * * *} \\
(0.0067)\end{array}$ & $\begin{array}{l}0.0093 \\
(0.0148) \\
\end{array}$ & $\begin{array}{l}0.0491^{* * *} \\
(0.0165)\end{array}$ \\
\hline & \multicolumn{2}{|c|}{$[N=89,421]$} & \multicolumn{2}{|c|}{$[\mathrm{N}=80,300]$} & \multicolumn{2}{|c|}{$[\mathrm{N}=9,121]$} \\
\hline
\end{tabular}

All models control for the covariates included in Table 4 combined with year and municipality fixed effects.

Cluster standard errors at municipality level are in parentheses. The numbers of observations are in brackets.

'*', '**' and '***' represent significance at the $10 \%, 5 \%$ and $1 \%$ levels, respectively.

Table 6: Results for multimorbidity patients: alternative pathways and by emergency and planned admissions (DiDiD estimates)

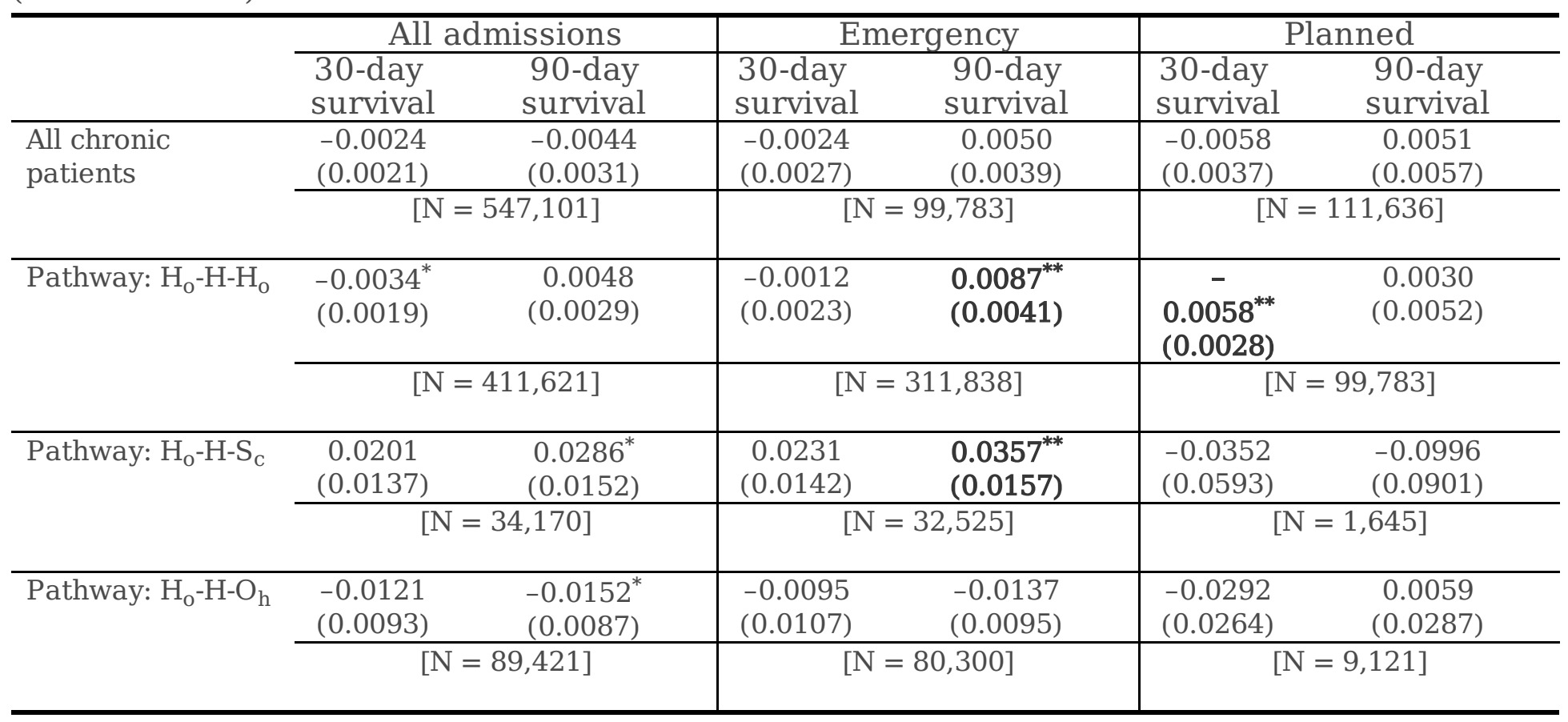

All models control for the covariates included in Table 4 combined with year and municipality fixed effects.

Cluster standard errors at municipality level are in parentheses. The numbers of observations are in brackets. 
'*', '**' and '***' represent significance at the $10 \%, 5 \%$ and $1 \%$ levels, respectively.

Table 7: Placebo reform results for chronic and multimorbidity patients: Difference-in-differences (DiD) and Difference-in-differences-in-differences (DiDiD) estimates

\begin{tabular}{|c|c|c|c|c|c|c|}
\hline & \multicolumn{2}{|c|}{ All admissions } & \multicolumn{2}{|c|}{ Emergency } & \multicolumn{2}{|c|}{ Planned } \\
\hline & $\begin{array}{l}\text { 30-day } \\
\text { survival }\end{array}$ & $\begin{array}{l}\text { 90-day } \\
\text { survival }\end{array}$ & $\begin{array}{l}\text { 30-day } \\
\text { survival }\end{array}$ & $\begin{array}{l}\text { 90-day } \\
\text { survival }\end{array}$ & $\begin{array}{l}\text { 30-day } \\
\text { survival }\end{array}$ & $\begin{array}{l}\text { 90-day } \\
\text { survival }\end{array}$ \\
\hline \multicolumn{7}{|l|}{ DiD estimates } \\
\hline \multirow[t]{2}{*}{ All chronic patients } & $\begin{array}{c}-0.0055^{* * *} \\
(0.0017)\end{array}$ & $\begin{array}{c}-0.0112^{* * *} \\
(0.0024)\end{array}$ & $\begin{array}{l}-0.0085^{* * *} \\
(0.0031)\end{array}$ & $\begin{array}{c}-0.0169^{* * *} \\
(0.0036)\end{array}$ & $\begin{array}{l}-0.0030 \\
(0.0018)\end{array}$ & $\begin{array}{c}-0.0073^{* *} \\
(0.0035)\end{array}$ \\
\hline & \multicolumn{2}{|c|}{$[\mathrm{N}=271,816]$} & \multicolumn{2}{|c|}{$[\mathrm{N}=217,687]$} & \multicolumn{2}{|c|}{$[\mathrm{N}=54,129]$} \\
\hline \multirow[t]{2}{*}{ Pathway: $\mathrm{H}_{\mathrm{o}}-\mathrm{H}-\mathrm{H}_{\mathrm{O}}$} & $\begin{array}{c}-0.0026^{* * *} \\
(0.0009)\end{array}$ & $\begin{array}{c}-0.0091^{* * *} \\
(0.0020)\end{array}$ & $\begin{array}{c}-0.0069^{* * *} \\
(0.0019)\end{array}$ & $\begin{array}{c}-0.0173^{* * *} \\
(0.0039)\end{array}$ & $\begin{array}{l}-0.0005 \\
(0.0013) \\
\end{array}$ & $\begin{array}{l}-0.0034 \\
(0.0032) \\
\end{array}$ \\
\hline & \multicolumn{2}{|c|}{$[N=206,333]$} & \multicolumn{2}{|c|}{$[N=158,208]$} & \multicolumn{2}{|c|}{$[\mathrm{N}=48,125]$} \\
\hline \multirow[t]{2}{*}{ Pathway: $\mathrm{H}_{\mathrm{o}}-\mathrm{H}-\mathrm{S}_{\mathrm{C}}$} & $\begin{array}{c}0.0003 \\
(0.0095)\end{array}$ & $\begin{array}{c}0.0129 \\
(0.0154)\end{array}$ & $\begin{array}{l}-0.0028 \\
(0.0098)\end{array}$ & $\begin{array}{c}0.0067 \\
(0.0155)\end{array}$ & $\begin{array}{c}-0.1079^{* *} \\
(0.0427)\end{array}$ & $\begin{array}{c}-0.2099^{* * *} \\
(0.0605)\end{array}$ \\
\hline & \multicolumn{2}{|c|}{$[\mathrm{N}=11,567]$} & \multicolumn{2}{|c|}{$[\mathrm{N}=10,759]$} & \multicolumn{2}{|c|}{$[\mathrm{N}=808]$} \\
\hline \multirow[t]{2}{*}{ Pathway: $\mathrm{H}_{\mathrm{o}}-\mathrm{H}-\mathrm{O}_{\mathrm{h}}$} & $\begin{array}{c}-0.0295^{* * *} \\
(0.0065)\end{array}$ & $\begin{array}{c}-0.0336^{* * *} \\
(0.0073)\end{array}$ & $\begin{array}{c}-0.0287^{* * *} \\
(0.0078)\end{array}$ & $\begin{array}{c}-0.0327^{* * *} \\
(0.0079)\end{array}$ & $\begin{array}{l}-0.0205 \\
(0.0192)\end{array}$ & $\begin{array}{c}-0.0106 \\
(0.0195)\end{array}$ \\
\hline & \multicolumn{2}{|c|}{$[\mathrm{N}=46,964]$} & \multicolumn{2}{|c|}{$[\mathrm{N}=42,472]$} & \multicolumn{2}{|c|}{$[\mathrm{N}=4,492]$} \\
\hline \multicolumn{7}{|l|}{ DiDiD estimates } \\
\hline \multirow[t]{2}{*}{ All chronic patients } & $\begin{array}{l}-0.0104^{* * *} \\
(0.0037)\end{array}$ & $\begin{array}{c}-0.0238^{* * *} \\
(0.0047)\end{array}$ & $\begin{array}{l}-0.0064 \\
(0.0056) \\
\end{array}$ & $\begin{array}{c}-0.0211^{* * *} \\
(0.0067)\end{array}$ & $\begin{array}{l}-0.0132^{* * *} \\
(0.0038)\end{array}$ & $\begin{array}{l}-0.0302^{* * *} \\
(0.0082)\end{array}$ \\
\hline & \multicolumn{2}{|c|}{$[\mathrm{N}=271,816]$} & \multicolumn{2}{|c|}{$[\mathrm{N}=217,687]$} & \multicolumn{2}{|c|}{$[\mathrm{N}=54,129]$} \\
\hline \multirow[t]{2}{*}{ Pathway: $\mathrm{H}_{\mathrm{o}}-\mathrm{H}-\mathrm{H}_{\mathrm{O}}$} & $\begin{array}{c}-0.0052^{* *} \\
(0.0021)\end{array}$ & $\begin{array}{c}-0.0148^{* * *} \\
(0.0041)\end{array}$ & $\begin{array}{l}-0.0060 \\
(0.0035)\end{array}$ & $\begin{array}{c}-0.0150^{* *} \\
(0.0062)\end{array}$ & $\begin{array}{l}-0.0041 \\
(0.0033)\end{array}$ & $\begin{array}{c}-0.0216^{* * *} \\
(0.0076)\end{array}$ \\
\hline & \multicolumn{2}{|c|}{$[\mathrm{N}=206,333]$} & \multicolumn{2}{|c|}{$[\mathrm{N}=158,208]$} & \multicolumn{2}{|c|}{$[\mathrm{N}=48,125]$} \\
\hline \multirow[t]{2}{*}{ Pathway: $\mathrm{H}_{\mathrm{o}}-\mathrm{H}-\mathrm{S}_{\mathrm{C}}$} & $\begin{array}{c}0.0181 \\
(0.0205) \\
\end{array}$ & $\begin{array}{l}-0.0178 \\
(0.0273) \\
\end{array}$ & $\begin{array}{c}0.0338 \\
(0.0215) \\
\end{array}$ & $\begin{array}{l}-0.0031 \\
(0.0284) \\
\end{array}$ & $\begin{array}{c}-0.1347^{*} \\
(0.0733) \\
\end{array}$ & $\begin{array}{l}-0.0608 \\
(0.1096)\end{array}$ \\
\hline & \multicolumn{2}{|c|}{$[\mathrm{N}=11,567]$} & \multicolumn{2}{|c|}{$[\mathrm{N}=10,759]$} & \multicolumn{2}{|c|}{$[\mathrm{N}=808]$} \\
\hline \multirow[t]{2}{*}{ Pathway: $\mathrm{H}_{\mathrm{o}}-\mathrm{H}-\mathrm{O}_{\mathrm{h}}$} & $\begin{array}{l}-0.0181 \\
(0.0123) \\
\end{array}$ & $\begin{array}{c}-0.0366^{* * *} \\
(0.0127)\end{array}$ & $\begin{array}{l}-0.0220 \\
(0.0133)\end{array}$ & $\begin{array}{c}-0.0455^{* * *} \\
(0.0142)\end{array}$ & $\begin{array}{c}-0.0523 \\
(0.0420)\end{array}$ & $\begin{array}{l}-0.0382 \\
(0.0488)\end{array}$ \\
\hline & \multicolumn{2}{|c|}{$[\mathrm{N}=46,964]$} & {$[\mathrm{N}=4$} & $2,472]$ & {$[\mathrm{N}=$} & $=, 492]$ \\
\hline
\end{tabular}

All models control for the covariates included in Table 4 combined with year and municipality fixed effects.

Cluster standard errors at municipality level are in parentheses. The numbers of observations are in brackets.

'*', '**' and '***' represent significance at the $10 \%, 5 \%$ and $1 \%$ levels, respectively.

Table 8: Robustness checks after excluding small municipalities for chronic patients: DiD and DiDiD estimates 


\begin{tabular}{|c|c|c|c|c|c|c|}
\hline & \multicolumn{2}{|c|}{ All admissions } & \multicolumn{2}{|c|}{ Emergency } & \multicolumn{2}{|c|}{ Planned } \\
\hline & $\begin{array}{l}\text { 30-day } \\
\text { survival }\end{array}$ & $\begin{array}{l}\text { 90-day } \\
\text { survival }\end{array}$ & $\begin{array}{l}\text { 30-day } \\
\text { survival }\end{array}$ & $\begin{array}{l}\text { 90-day } \\
\text { survival }\end{array}$ & $\begin{array}{l}\text { 30-day } \\
\text { survival }\end{array}$ & $\begin{array}{l}\text { 90-day } \\
\text { survival }\end{array}$ \\
\hline \multicolumn{7}{|l|}{ DiD estimates } \\
\hline \multirow[t]{2}{*}{ All chronic patients } & $\begin{array}{l}0.0050^{* * *} \\
(0.0018)\end{array}$ & $\begin{array}{c}0.0068^{* * *} \\
(0.0019)\end{array}$ & $\begin{array}{l}0.0089^{* *} \\
(0.0034)\end{array}$ & $\begin{array}{c}0.0063^{*} \\
(0.0036)\end{array}$ & $\begin{array}{c}0.0000 \\
(0.0016)\end{array}$ & $\begin{array}{l}0.0054^{* *} \\
(0.0027)\end{array}$ \\
\hline & \multicolumn{2}{|c|}{$[\mathrm{N}=423,539]$} & \multicolumn{2}{|c|}{$[\mathrm{N}=338,553]$} & \multicolumn{2}{|c|}{$[\mathrm{N}=84,986]$} \\
\hline \multirow[t]{2}{*}{ Pathway: $\mathrm{H}_{\mathrm{o}}-\mathrm{H}-\mathrm{H}_{\mathrm{o}}$} & $\begin{array}{c}-0.0003 \\
(0.0010)\end{array}$ & $\begin{array}{c}0.0020 \\
(0.0015)\end{array}$ & $\begin{array}{c}0.0014 \\
(0.0018)\end{array}$ & $\begin{array}{c}0.0020 \\
(0.0031)\end{array}$ & $\begin{array}{l}-0.0011 \\
(0.0011)\end{array}$ & $\begin{array}{c}0.0023 \\
(0.0022)\end{array}$ \\
\hline & \multicolumn{2}{|c|}{$[\mathrm{N}=319,218]$} & \multicolumn{2}{|c|}{$[\mathrm{N}=243,212]$} & \multicolumn{2}{|c|}{$[N=76,006]$} \\
\hline \multirow[t]{2}{*}{ Pathway: $\mathrm{H}_{\mathrm{o}}-\mathrm{H}-\mathrm{S}_{\mathrm{c}}$} & $\begin{array}{c}0.0146^{*} \\
(0.0079)\end{array}$ & $\begin{array}{c}0.0181 * \\
(0.0094)\end{array}$ & $\begin{array}{c}0.0122 \\
(0.0081)\end{array}$ & $\begin{array}{c}0.0136 \\
(0.0093)\end{array}$ & $\begin{array}{c}-0.0624^{* *} \\
(0.0270)\end{array}$ & $\begin{array}{c}-0.1448^{* * * *} \\
(0.0459)\end{array}$ \\
\hline & \multicolumn{2}{|c|}{$[N=27,320]$} & \multicolumn{2}{|c|}{$[\mathrm{N}=26,070]$} & \multicolumn{2}{|c|}{$[N=1,250]$} \\
\hline \multirow[t]{2}{*}{ Pathway: $\mathrm{H}_{\mathrm{o}}-\mathrm{H}-\mathrm{O}_{\mathrm{h}}$} & $\begin{array}{c}0.0159^{*} \\
(0.0083)\end{array}$ & $\begin{array}{c}0.0253^{* * * *} \\
(0.0084)\end{array}$ & $\begin{array}{l}0.0217^{* * *} \\
(0.0080)\end{array}$ & $\begin{array}{c}0.0293^{* * *} \\
(0.0083)\end{array}$ & $\begin{array}{c}0.0022 \\
(0.0167)\end{array}$ & $\begin{array}{l}0.0405^{* *} \\
(0.0188)\end{array}$ \\
\hline & \multicolumn{2}{|c|}{$[\mathrm{N}=68,198]$} & \multicolumn{2}{|c|}{$[\mathrm{N}=61,297]$} & \multicolumn{2}{|c|}{$[\mathrm{N}=6,901]$} \\
\hline \multicolumn{7}{|l|}{ DiDiD estimates } \\
\hline \multirow[t]{2}{*}{ All chronic patients } & $\begin{array}{l}-0.0023 \\
(0.0023)\end{array}$ & $\begin{array}{c}0.0047 \\
(0.0036)\end{array}$ & $\begin{array}{l}-0.0028 \\
(0.0030)\end{array}$ & $\begin{array}{c}0.0042 \\
(0.0043)\end{array}$ & $\begin{array}{l}-0.0066 \\
(0.0042) \\
\end{array}$ & $\begin{array}{c}0.0054 \\
(0.0065)\end{array}$ \\
\hline & \multicolumn{2}{|c|}{$[\mathrm{N}=423,539]$} & \multicolumn{2}{|c|}{$[\mathrm{N}=338,553]$} & \multicolumn{2}{|c|}{$[\mathrm{N}=84,986]$} \\
\hline \multirow[t]{2}{*}{ Pathway: $\mathrm{H}_{\mathrm{o}}-\mathrm{H}-\mathrm{H}_{\mathrm{O}}$} & $\begin{array}{c}-0.0018 \\
(0.0021)\end{array}$ & $\begin{array}{c}0.0054 \\
(0.0033) \\
\end{array}$ & $\begin{array}{c}0.0003 \\
(0.0028)\end{array}$ & $\begin{array}{c}0.0083^{*} \\
(0.0047)\end{array}$ & $\begin{array}{l}-0.0060^{*} \\
(0.0032) \\
\end{array}$ & $\begin{array}{c}0.0044 \\
(0.0060) \\
\end{array}$ \\
\hline & \multicolumn{2}{|c|}{$[\mathrm{N}=319,218]$} & \multicolumn{2}{|c|}{$[\mathrm{N}=243,212]$} & \multicolumn{2}{|c|}{$[\mathrm{N}=76,006]$} \\
\hline \multirow[t]{2}{*}{ Pathway: $\mathrm{H}_{\mathrm{O}}-\mathrm{H}-\mathrm{S}_{\mathrm{C}}$} & $\begin{array}{c}0.0168 \\
(0.0155)\end{array}$ & $\begin{array}{c}0.0224 \\
(0.0168)\end{array}$ & $\begin{array}{c}0.0218 \\
(0.0158)\end{array}$ & $\begin{array}{c}0.0307^{*} \\
(0.0173)\end{array}$ & $\begin{array}{l}-0.0340 \\
(0.0666)\end{array}$ & $\begin{array}{l}-0.1018 \\
(0.1025)\end{array}$ \\
\hline & \multicolumn{2}{|c|}{$[\mathrm{N}=27,320]$} & \multicolumn{2}{|c|}{$[\mathrm{N}=26,070]$} & \multicolumn{2}{|c|}{$[\mathrm{N}=1,250]$} \\
\hline \multirow[t]{2}{*}{ Pathway: $\mathrm{H}_{\mathrm{o}}-\mathrm{H}-\mathrm{O}_{\mathrm{h}}$} & $\begin{array}{l}-0.0168 \\
(0.0106) \\
\end{array}$ & $\begin{array}{c}-0.0128 \\
(0.0100) \\
\end{array}$ & $\begin{array}{l}-0.0153 \\
(0.0121) \\
\end{array}$ & $\begin{array}{c}-0.0127 \\
(0.0109) \\
\end{array}$ & $\begin{array}{c}-0.0353 \\
(0.0291) \\
\end{array}$ & $\begin{array}{c}-0.0037 \\
(0.0325) \\
\end{array}$ \\
\hline & \multicolumn{2}{|c|}{$[\mathrm{N}=68,198]$} & \multicolumn{2}{|c|}{$[\mathrm{N}=61,297]$} & {$[\mathrm{N}=$} & $5,901]$ \\
\hline
\end{tabular}

All models control for the covariates included in Table 4 combined with year and municipality fixed effects.

Cluster standard errors at municipality level are in parentheses. The numbers of observations are in brackets. '**' and '***' represent significance at the $5 \%$ and $1 \%$ levels, respectively.

\section{Figures}



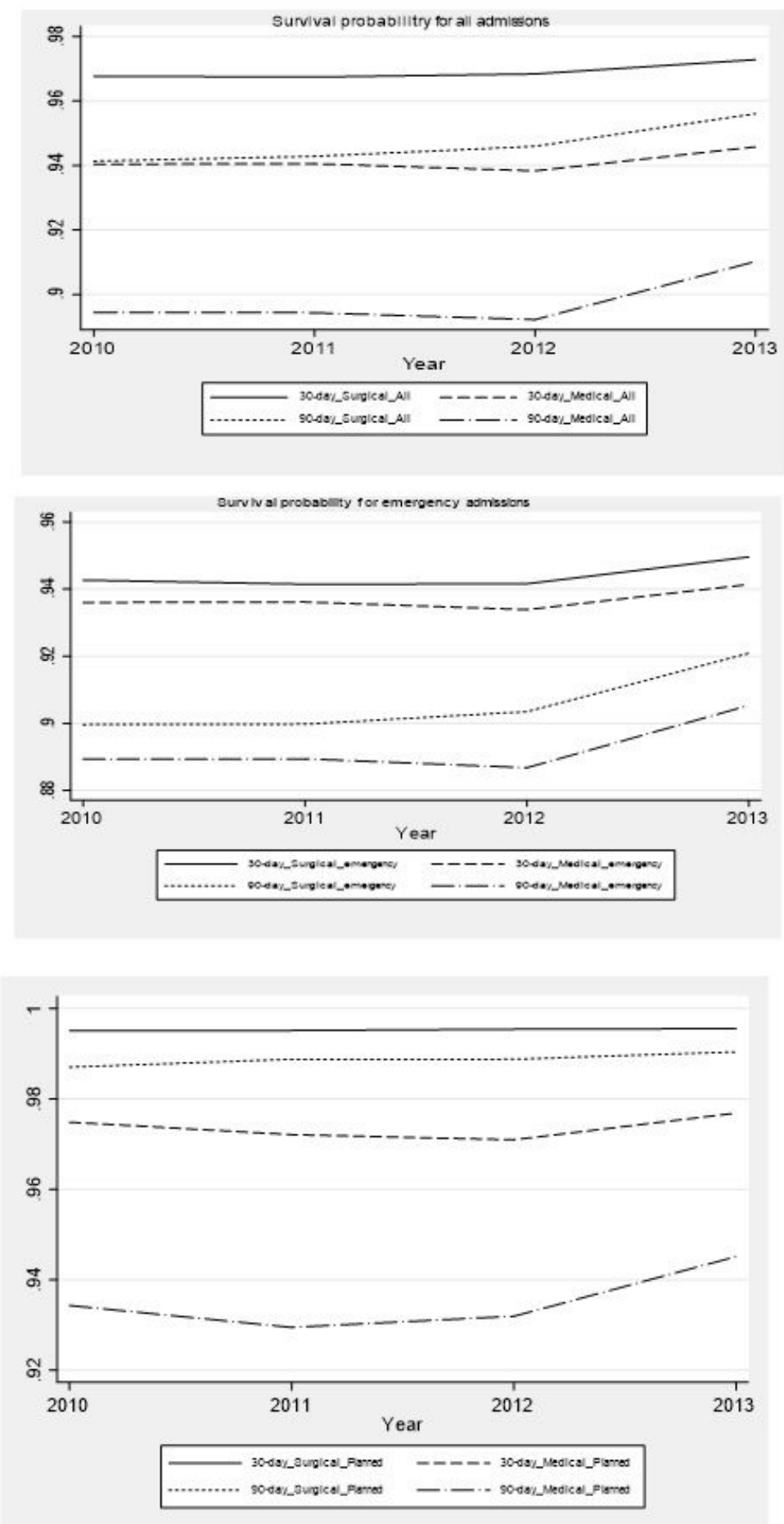

\section{Figure 1}

30-day and 90-day Survival probability of surgical and medical diagnostics, and by emergency and planned admissions for 30 chronic conditions

\section{Supplementary Files}


This is a list of supplementary files associated with this preprint. Click to download.

- BMCHSRSupplementaryMaterials.pdf 